\title{
Civil Society, Public Action and Accountability in Africa
}

\section{Citation}

Devarajan, Shantayanan, Stuti Khemani, and Michael Walton. 2011. Civil Society, Public Action and Accountability in Africa. HKS Faculty Research Working Paper Series RWP11-036, John F. Kennedy School of Government, Harvard University.

\section{Published Version}

http://web.hks.harvard.edu/publications/workingpapers/citation.aspx?Publd=7968

\section{Permanent link}

http://nrs.harvard.edu/urn-3:HUL.InstRepos:5131503

\section{Terms of Use}

This article was downloaded from Harvard University's DASH repository, and is made available under the terms and conditions applicable to Other Posted Material, as set forth at http:// nrs.harvard.edu/urn-3:HUL.InstRepos:dash.current.terms-of-use\#LAA

\section{Share Your Story}

The Harvard community has made this article openly available.

Please share how this access benefits you. Submit a story.

Accessibility 


\section{Civil Society, Public Action and Accountability in Africa Faculty Research Working Paper Series}

\section{Shantayanan Devarajan}

World Bank

\section{Stuti Khemani}

World Bank

\section{Michael Walton}

Harvard Kennedy School and Centre for Policy Research, New Delhi

\section{September 2011}

RWP11-036

The views expressed in the HKS Faculty Research Working Paper Series are those of the author(s) and do not necessarily reflect those of the John F. Kennedy School of Government or of Harvard University. Faculty Research Working Papers have not undergone formal review and approval. Such papers are included in this series to elicit feedback and to encourage debate on important public policy challenges. Copyright belongs to the author(s). Papers may be downloaded for personal use only. 


\section{Policy Research Working Paper 5733}

\section{Civil Society, Public Action and Accountability in Africa}

Shantayanan Devarajan

Stuti Khemani

Michael Walton

The World Bank

Development Research Group

Human Development and Public Services Team

July 2011 
Policy Research Working Paper 5733

\begin{abstract}
This paper examines the potential role of civil society action in increasing state accountability for development in Sub-Saharan Africa. It further develops the analytical framework of the World Development Report 2004 on accountability relationships, to emphasize the underlying political economy drivers of accountability and implications for how civil society is constituted and functions. It argues on this basis that the most important domain for improving accountability is through the political relations between citizens, civil society, and state leadership. The evidence broadly suggests that when higher-level political leadership provides sufficient or appropriate powers for citizen participation in holding
\end{abstract}

within-state agencies or frontline providers accountable, there is frequently positive impact on outcomes.

However, the big question remaining for such types of interventions is how to improve the incentives of higher-level leadership to pursue appropriate policy design and implementation. The paper argues that there is substantial scope for greater efforts in this domain, including through the support of external aid agencies. Such efforts and support should, however, build on existing political and civil society structures (rather than transplanting "best practice" initiatives from elsewhere), and be structured for careful monitoring and assessment of impact.

This paper is a product of the Human Development and Public Services Team, Development Research Group. It is part of a larger effort by the World Bank to provide open access to its research and make a contribution to development policy discussions around the world. Policy Research Working Papers are also posted on the Web at http://econ.worldbank.org. The author may be contacted at skhemani@worldbank.org.

The Policy Research Working Paper Series disseminates the findings of work in progress to encourage the exchange of ideas about development issues. An objective of the series is to get the findings out quickly, even if the presentations are less than fully polished. The papers carry the names of the authors and should be cited accordingly. The findings, interpretations, and conclusions expressed in this paper are entirely those of the authors. They do not necessarily represent the views of the International Bank for Reconstruction and Development/World Bank and its affliated organizations, or those of the Executive Directors of the World Bank or the governments they represent. 


\section{Civil Society, Public Action and Accountability in Africa}

\author{
Shantayanan Devarajan ${ }^{1}$ \\ World Bank
}

\author{
Stuti Khemani \\ World Bank
}

\author{
Michael Walton \\ Harvard University \\ and Centre for Policy \\ Research, New Delhi
}

\footnotetext{
${ }^{1}$ Shantayanan Devarajan is Chief Economist of the Africa Region of The World Bank. Stuti Khemani is Senior Economist in the Development Research Group of the World Bank. Michael Walton is Lecturer in International Development at the Harvard Kennedy School of Government, and Senior Visiting Fellow at the Centre for Policy Research, New Delhi. We are grateful to Avnish Gungadurdoss for excellent research assistance, and the preparation of a literature review that is appended to this paper. Corresponding author: Stuti Khemani, Development Research Group, The World Bank, $1818 \mathrm{H}$ Street NW, Washington DC 20433, skhemani@ worldbank.org. Disclaimer: The findings, interpretations, and conclusions expressed in this paper are entirely those of the author, and do not necessarily represent the views of the World Bank, its Executive Directors, or the countries they represent.
} 


\section{Introduction}

Consider the following facts:

- Teachers in public primary schools in Uganda are absent 20 percent of the time; when present, they are in class teaching 18 percent of the time (Chaudhury et al, 2006, World Bank, 2007).

- Only 1 percent of non-salary expenditures allocated to primary health clinics in Chad actually reach the clinics (Gauthier and Wane, 2005).

- There are huge leakages from fertilizer subsidies in Tanzania, with elected officials receiving 60 percent of the vouchers (Pan and Christiansen, 2011).

- Efforts to hire workers below the minimum wage in South Africa-a country whose unemployment rate is 25 percent-are met with widespread, sometimes violent, protest.

- Thanks to regulations that prohibit entry, monopoly rents to trucking companies cause Africa to have the highest transport prices in the world (Teranavithorn and Raballand, 2009).

In addition to being emblematic of problems facing poor people in Africa, these facts have one more thing in common: they can be explained by failures of

"accountability" at various points in the chain of relationships in the implementation of public sector policies. This chain goes from the preferences and needs of citizens, through the political process, and then passes to the bureaucracies and front-line actors charged with delivering services, or to the regulators, judges and others with responsibility for monitoring and enforcing economic and social behavior. Teacher absenteeism or leakage of public funds are examples of politicians or central-level bureaucrats being unable (or unwilling) to hold lower-level bureaucrats and service providers accountable. Capture of fertilizer subsidies or wage premiums by politically powerful groups are instances of citizens' inability to hold politicians accountable. ${ }^{2}$

An approach to improving state accountability through public action by civil society, that has long been advocated and practiced by local and international nongovernmental organizations, has more recently become of interest to the development financing community of bilateral and multilateral donors, including the World Bank.

\footnotetext{
2 It is important to note that these are not problems that can be solved by rolling back the state. For a wide range of goods and policies, the state has an important role to play in facilitating markets, growth poverty reduction, and human development. The concern is how to make the state more accountable for better development policies.
} 
Does a substantially strengthened role for civil society have a sound conceptual and empirical basis, or is it just another fad? Where civil society influences state action, is it always in the direction of better provision of public goods, equitable human development and dynamic capitalist advance? Or does civil society also reflect the inequalities in wealth, organization and influence in the political process? What is the relationship between civil society action to make the state work better for all citizens, and formal political and governmental mechanisms of accountability? And even if there is a sound, substantiated case for some forms of strengthening of civil society, can external actors play a useful role in supporting it, or will they just add a new set of distortions?

This paper seeks to provide answers to these questions, drawing on a structured review of the available literature and development experience in these areas. First, it reviews the analytics of accountability relationships, linking the core accountability relationship to the broader political economy of African societies, the democratization process, and the potential role of civil society. Second, against that analytical framework, the paper reviews the available evidence from current attempts to improve accountability through civil society-related interventions, focusing on empirically rigorous and carefully documented studies. The theme here is civil society action as a means to the pragmatic ends of development-growth, poverty reduction, health, education-rather than an objective in and of itself.

The analytics and evidence support a common conclusion. There is indeed a strong prima facie case for a strengthened role for civil society, to differing degrees and forms in both democratic and at least semi-authoritarian regimes. However, strategies and interventions in this regard need to be cognizant of underlying political economy drivers of failures in accountability. In political economy environments characterized by high degrees of clientelism and rent-seeking, such as are widespread in the Africa region, an unqualified faith in civil society as a force for good is more likely to be misplaced. The evidence base on the organization of civil society suggests that historic institutions of poverty and inequality, or of ethnic identity, can inhibit collective action in the broader public interest, promote more narrow sectarian interests, and nourish clientelist political competition.

Furthermore, broad collective or public-interest action by civil society is heavily constrained by existing systems and institutions of the state. However, there is also substantial potential for civil society action to achieve success in addressing accountability failures, incremental and transformational, with the focus here on conditions under which incremental changes can emerge. 
What does this mean for domestic, and especially external, actors? It implies that support for civil society should follow an approach that is both organic and experimental: organic in the sense that interventions contribute to change in existing political and societal structures, and not seek to bring "best practice" ideas from outside; experimental in the sense of that there be structured monitoring, information generation and evaluation in the process-with the techniques depending on the nature of the intervention.

In the next section, we unbundle the different accountability relationships and explore how, depending on the nature of the "failure," civil society action may or may not help. The following section summarizes our review of the existing evidence on the impact of civil society related initiatives to improve accountability. A final section discusses the implications for external actors.

\section{The analytics of accountability and civil society action in a Sub-Saharan context}

\subsection{The long and short routes of accountability}

The 2004 World Development Report (WDR), Making Services Work for Poor People, postulated that problems in the delivery of basic services-such as the teacher absenteeism, leakage of public funds or poorly targeted fertilizer subsidies described above-could be interpreted as breaks in the "long route of accountability." The argument was as follows. In a private market transactionsuch as buying a sandwich from a vendor-there is direct accountability of the sandwich provider to the client or consumer. The client pays the vendor directly; she can observe whether or not she received the sandwich; and, if the market is reasonably competitive, the client can go elsewhere if she doesn't like the sandwich-and the vendor knows that. The WDR called this relationship the "short route of accountability."

When public action is involved, the relationship between the client and the service provider is no longer a direct one, but an indirect one, intermediated by the state. In the case of education, for instance, citizens as voters hold politicians accountable for allocating resources and regulating the education system. In turn, politicians or policymakers hold teachers accountable for delivering the service. This is the long route of accountability (Figure 1). Viewed in this light, it is easy to see how service delivery failures can be interpreted as a breakdown in one or both of the links in the long route of accountability. Teacher absenteeism is the result of policymakers' inability (or unwillingness) to monitor teachers' performance in the classroom. 
Even if they can monitor performance, they may not be able to enforce penalties for non-performance because of the nature of the contract between teachers and the state (most teachers' salaries are fixed, independent of attendance).

\section{Figure 1: The Long and Short Routes of Accountability}

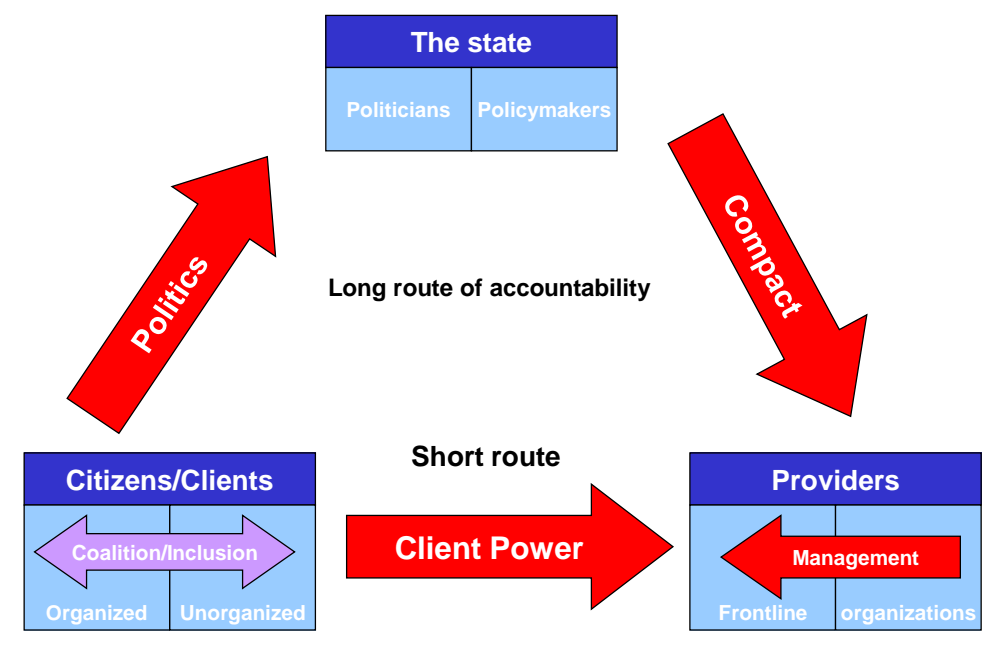

However, in the case of teacher absenteeism, there is the further question of how the contracts get determined in the first place, and why it is so difficult to change them, to make them more sensitive to performance. The answer lies in the first link in the long route-the relationship between citizens and politicians. Even if a majority of voters would prefer less absenteeism, there are significant failures in the political process that result in politicians who favor the status quo getting elected, and those attempting to address the problem of teacher accountability losing elections. These political failures take on many forms, and in the case of education, there are some specific causes. In many rural areas, teachers are also political organizers, so that politicians rely on them to deliver votes. The South African Democratic Teachers Union (SADTU), part of the governing coalition, is one of the most powerful trade unions in the country. In the state legislature of the Indian state of Uttar Pradesh, teachers constitute 20 percent of the assembly in the early 2000s, and former teachers another 20 percent (Kingdon and Muzammil, 2001). 
The relationships of accountability-the politics between citizens and policymakers, the compact between policymakers and providers, and the client power of citizens over providers-are determined by the behavior, incentives and organization of each set of actors in the "nodes". There can be considerable heterogeneity within each of these nodes. Citizens can become organized as interest groups, to service the objectives of their group, even at the expense of broad public interest; formally unorganized citizens can demand broad public interest policies (or not) through the aggregate effect of their individual participation in elections. Politicians and providers (a variety of state agents) can similarly be heterogeneous in their motivations, incentives and organization, with some having more intrinsic motivation and stronger incentives for development objectives, while that of others is inclined to extraction of private benefits.

The central question of this paper is how citizen behavior, incentives and organization can be influenced to improve the functioning of politics, compact, and client power? How can citizen action contribute to the selection of better quality political and state agents, and strengthen incentives of all types of agents to deliver effective development policies?

We re-interpret the WDR accountability triangle here by emphasizing the underlying political economy drivers of accountability. The politics between citizens and policymakers, previously characterized in the WDR 2004 as the "voice" relationship, is argued to be the more fundamental relationship of accountability in that it shapes the nature of the compact and client power. Civil society action can help to the degree that it can fix failures in political incentives for development policies; or in cases when the political leadership has incentives to use civil society input to address failures in the compact and client power. Even when political incentives allow interventions that enable civil society action to improve the compact and/or client power, the question has to be asked whether there are other mechanisms that political agents could have used to improve the performance of state agents and providers which rely less on citizen effort and time and more on political agent effort and time, or by reducing political rents.

Accountability solutions, and associated failures, relate to three mechanisms, with strong complementarities between them:

- Information

- Collective action

- Sanctions

Political accountability failures could be attributed to asymmetric information about the performance of public policies; lack of coordination or collective action among citizens in evaluating politicians on the basis of broad public interest policies (as opposed to the basis of ethnic identity, or narrowly targeted clientelist transfers); 
and lack of effective sanctioning mechanisms such as through an independent election commission, that monitors free and fair elections.

Weak compacts can be derived from weak politics, when policymakers do not use instruments at their disposal to address information constraints in monitoring providers or to strengthen organizational incentives and sanctioning mechanisms within public agencies. A highly committed senior education officer will be able to do little if teachers are hired as political patronage and not to teach; a mining official determined to meet citizen complaints of flouting environmental standards will not be tolerated if politicians are party to rent-sharing deals with the mining companies. However, even in cases where higher tier political authorities have incentives to reduce rent-seeking at lower levels, lack of information and managerial constraints on enforcing sanctions can lead to failures in the compact.

Weak client power can also be derived from weak politics, such as when states provide weak grievance mechanisms (sanctions) and limit choice among providers through state policies. Furthermore, very local institutions of inequality can make poor citizens powerless against local social and economic elite who can be the providers of most state and private services. That is, client power is hobbled by asymmetric information and institutional constraints to collective action and sanctions.

Civil society action in Africa and elsewhere has focused on ways in which information provision and other activities mobilize citizens for collective action and demands for redress. These may be localized islands, where social pressures improve the performance of frontline providers. Or there can be particular sectors or agencies that are effective and responsive, and use citizen inputs to monitor the performance of providers and sanction poor behaviors. These islands of collective and effective action can be of great interest as to what can be done, and may be signs of potential for broader change. But they can also be deceptive if they do not reflect overall political strategies, making scaling of development results (even if not the specific interventions) problematic.

Civil society's effectiveness will almost always depend on incentives, and in particular the activation of sanctioning mechanisms, within the state. These may take the form of internal bureaucratic structures within implementing agencies, or formally independent institutions of accountability within the state, including the legislature, judiciary, auditing departments etc. In practice, however, such institutions are often either weak or not substantively independent. The effectiveness of such internal mechanisms will depend on their being aligned with 
political strategies, especially over the medium to long term. It is in this sense, that we regard the relationship of politics, that reflects underlying structures of power in a society, as being the primary influence on overall accountability relations.

\subsection{Political economy drivers of accountability relations}

Recent theoretical advances in understanding development, or the persistent lack of it, have emphasized the role of long-term institutions that continue to shape the current political economy of countries. Institutions are interpreted as products of long-term interactions among elite groups and between elites and middle and poorer groups (North et al, 2009; Acemoglu et al, 2001, 2005; Engerman and Sokoloff, 1997; Rajan, 2009). Important themes are of state formation as a response to the threat of violence between competing groups, and of institutional resolutions that often reflect the interests of elites, in environments of highly unequal distribution of endowments. Institutional resolutions, involving "extractive" economic institutions (Acemoglu and Robinson, Forthcoming) can be good for political and economic elites, while also sustaining inequalities and inhibiting the innovation, entry and investment that is necessary for long-term growth. Related strands examine the role of historical colonial institutions in creating or sustaining inequality, which then leads to persistence of elites and poor institutions that inhibit development (Acemoglu et al, 2001).

Two kinds of rent-sharing arrangements are of importance to the functioning of the polity and the economy.

First, there are bargains between competing elites, and between political and economic elites. Effective bargains with strong incentives against reneging are necessary for overall political stability, since excluded elite groups will otherwise mobilize to topple rulers to capture the rents. In particular a credible commitment by political elites not to expropriate economic elites is crucial to the investment and innovation that drive aggregate growth. ${ }^{3}$ In mature, consolidated democracies credible commitment against such expropriation is provided by the array of institutions that guarantee the rule of law, and protect businesses and individuals from opportunistic behavior of agents of the state. Under authoritarian polities, political elites in control of the state also use force-despotic power ${ }^{4}$ - to prevent

\footnotetext{
${ }^{3}$ See Haber et al (2003) for a historically based development of this argument for Mexico in the $20^{\text {th }}$ century.

${ }^{4}$ By despotic power, we mean the capacity of the state elite to coerce and dominate civil society classes, including other social and economic elites and middle and subordinate groups. Mann (1986) contrasts this with "infrastructural power" that involves provision of public goods and services,
} 
competing groups from taking over the state. However, for economic investment to occur, there must also be mechanisms that make it costly for the political elites to expropriate productive investments. One mechanism is the mingling of political and economic elites by social, marital and cultural ties. ${ }^{5}$

Sharing of rents among different elite groups is a pervasive institutional form in Africa (van de Walle, 2001). Cote d'Ivoire is an example of a case in which the credible management of such a sharing system by then President Houphouet-Boigny was central to the country's stability; this lost credibility and spilled over into conflict on his death (Azam, 2001). In post-apartheid, democratic South Africa, the Black Economic Empowerment policy is effectively a mechanism to share rents with the emerging black elite (Andrews, 2008; Acemoglu et al, 2007).

Second, there is rent-sharing with middle and poorer groups-that may include formal sector workers, slum-dwellers, large and small farmers, landless rural workers and so on-in return for their political support. The extent to which this is necessary again depends on the nature and power of the regime: regimes with high levels of despotic power will be able to use repression to maintain order under conditions of high inequality and political or social exclusion. However, this is sustainable only with substantial resources to maintain the repressive apparatus (including rent-sharing with the army and police). Some redistribution is necessary to subordinate groups to avert social revolt even in authoritarian societies. Under democratic auspices this is clearly even more relevant. Moreover, where subordinate groups are sufficiently organized to threaten an authoritarian regime, a democratic transition will be demanded to ensure that any concessions (economic, social or political) are credible-otherwise the elites will have every incentive to reverse the concessions if they can restore their organizational capacity and associated despotic power. ${ }^{6}$

These two sets of rent-sharing political arrangements provide the underlying structure to the politics relationship. In each domain, the rent-sharing arrangements are functional to both the stability of the polity and to the economic investment and the expansion of employment and services. But each also brings with it intrinsic state maladies - problematic aspects of state functioning with

regulation of private activity and raising taxes over the whole of a nation's territory; this intrinsically depends on the behavior of households, firms and civil society.

${ }^{5}$ Haber et al (2003) explore the systematic role of third party enforcement, even in Mexico's turbulent revolutionary period, by many mechanisms, including the one referred to in the text. 6 Acemoglu and Robinson (2006) build a theory of democratic transitions around this insight: arguing that a transition to democracy is more likely the more unequal is a society and the greater the costs of repression 
respect to both efficiency and equity. In particular, in both domains they are associated with under-provision of public goods and the perpetuation of economic, political and social inequalities.

With respect to inter-elite bargains, the main maladies are the failure to deliver the general public goods of credible commitment to investors (including small, informal firms), the rule of law and market institutions that support entry and competition. This is the flipside of the extraction and appropriation of rents by elite groupswhether through creation of monopolies, extraction of surpluses from the population (e.g. through state agricultural boards) or mining and other natural resources. This is typically associated with a tight nexus between political influence and economic resources.

With respect to rent-sharing with middle and poorer groups, the dominant political strategy is of clientelism: the provision, via state resources, of private benefits to particular groups in return for their political loyalty. The literature on clientelism suggests it comes in two different forms (e.g. Kitschelt and Wilkinson, 2007; Vicente and Wantchekon, 2008): targeted benefits to citizens that depend on the holding of political power, such as jobs in the public sector (Robinson and Verdier, 2003; Keefer and Vlaicu, 2008), or "club" goods to particular localities or groups; and petty benefits to less organized supporters, through vote buying, which can also be offered by competitors who are not current incumbents.

A more extreme malady comes in the form of use of the state apparatus to predate on the population and the country's resources by the political elite in power. This is typically associated with extensive use of despotic power.

In the African context, both rent-sharing among elite groups, and clientelism are often linked to identity-based groups, of ethnicity, religion or region (or all three overlapping, as they do in Nigeria and Sudan). However, this is by no means necessarily the case: in Tanzania, ethnicity is not salient in politics, in part due to a concerted nation-building strategy. Yet clientelism is still rampant (Kelsall, 2002). Nor are such identity-based links peculiar to Africa: India is a consolidated democracy in which identity of caste and religion is highly politically salient: Chandra (2004) develops the case that patronage on identity-lines is a rational response to the overall clientelistic character of the polity.

While these rent-sharing arrangements are most directly part of the basic political structuring of the politics relationship, they also profoundly influence the compact 
and client power relationships, and bring associated maladies. This is for three reasons:

- Bureaucracies and other un-elected positions are in most of Sub-Saharan Africa thoroughly embedded in political and social relations (South Africa is the most important exception of a country with something close to a Weberian bureaucracy). Indeed, far from "seeing like a state", in James Scott's characterization of high modernist state functioning, for many African states it is more a question of "looking like a state"7. Elite bargains and clientelism are effected through the behavior of bureaucracies, and sometimes judiciaries and other state actors, as much as through the political process.

- Where bureaucratic, judicial and other "compact" positions are allocated as a form of patronage (to family, friends, co-ethnics, etc), the incentive structure is intrinsically about the reciprocal provision of political loyalty, on an individual or group basis, as opposed to delivery of a service. This is consistent with the malady of low effort, such as teacher absenteeism, that was highlighted in the examples in the introduction to this paper.

- A structurally ineffective state can be part of a self-perpetuating equilibrium. Even if shifts in the politics relation lead to a politician wanting to deliver public goods, he or she may be unable to do so, given the weakness of the state as a lever to do precisely this. A clientelistic political strategy may be forced upon him or her.

These issues apply throughout the state compact system, all the way to the frontline of service delivery. It thus also pervades the client power relation, though street-level workers are even more likely to be embedded in local political and social structures. Sometimes this can lead to direct social pressures for better services, but it can also lead to reinforcing of the generic maladies of the state (see discussion of evidence below).

The two rent-sharing relations are also central to the creation and reproduction of inequalities. The extraction and appropriation of rents by elites is a primary source of inequality, while clientelistic strategies are a classic political strategy for sustaining sufficient support from middle and poorer groups under unequal terms. Clientelism also tends to favor those groups with greater capacity to organize (e.g.

\footnotetext{
7 This phrase is due to anthropologist Steven Pierce in his work on Nigeria [Pierce, 2006]; the theme is also emphasized in the neo-patrimonial and other literatures on the African state (e.g. van de Walle, 2001)
} 
unions, organized special interest groups) or with ethnic, geographic or other identity-based ties to elites in power.

Finally, corruption is intricately linked to these systems. It is facilitated by the combination of creation of rents that are controlled by state (or sometimes nonstate) actors. It is also linked to both forms of rent-sharing, manifest in high-level corruption in major business deals, and the widespread petty corruption faced by citizens in their daily lives. It is also linked to patterns of inequality, since it typically benefits political and business elites in the sharing of rents, and, at a lower level, officials in public sector jobs.

These deeply embedded political economy and institutional drivers of accountability are being subject to incremental changes through at least two powerful forces developing in Africa-increasing political competitiveness, and greater organization and communication among citizens. We discuss each of these trends in turn, to examine how they might be leveraged for greater civil society action for accountability.

\subsection{Accountability and democratization in Africa}

Data from the Polity IV effort, which uses expert opinion of political scientists to categorize the extent of autocracy and democracy of a regime, can be used to illustrate the nature of the democratic change moving across Africa over the past 20 years. There is a continuum of regimes, from completely autocratic to a fully consolidated democracy, with a large range of intermediate types (that they refer to as "anocracies") that have elements of both autocratic and democratic processes. Their synthetic classification uses a numerical system, in which -10 to -7 are classified as autocratic, -6 to +6 as intermediate, and +7 to +10 as democratic.

Figure 2 illustrates both the size of the change between 1985 and 2009, and the current classification for most of the countries. In the mid-1980s, 31 out of a total of 40 in the data base were fully autocratic, with only two full-fledged democracies (Gambia and Mauritius), and 6 intermediate regimes, most of which had a heavy weight of autocracy. By end-2009, the Polity IV classification has 12 fully democratic regimes (Benin, Botswana, Comoros, Ghana, Kenya, Lesotho, Mali, Mauritius, Senegal, Sierra Leone, South Africa and Zambia) and only 3 fully autocratic (Eritrea, Somalia and Swaziland ${ }^{8}$ ) with a majority being classified as

\footnotetext{
8 Eritrea and Somalia are not included in the figure, as data was not available for the earlier year.
} 
intermediate, or "anocratic", regimes, most with significant democratic elements (including, for example, Burkina Faso, Côte d'Ivoire, the Democratic Republic of Congo, Ethiopia, Mozambique, Nigeria, Rwanda, Uganda, Tanzania and Zimbabwe).

Figure 2: Democratic and autocratic regimes in SubSaharan Africa, 1985 and 2009

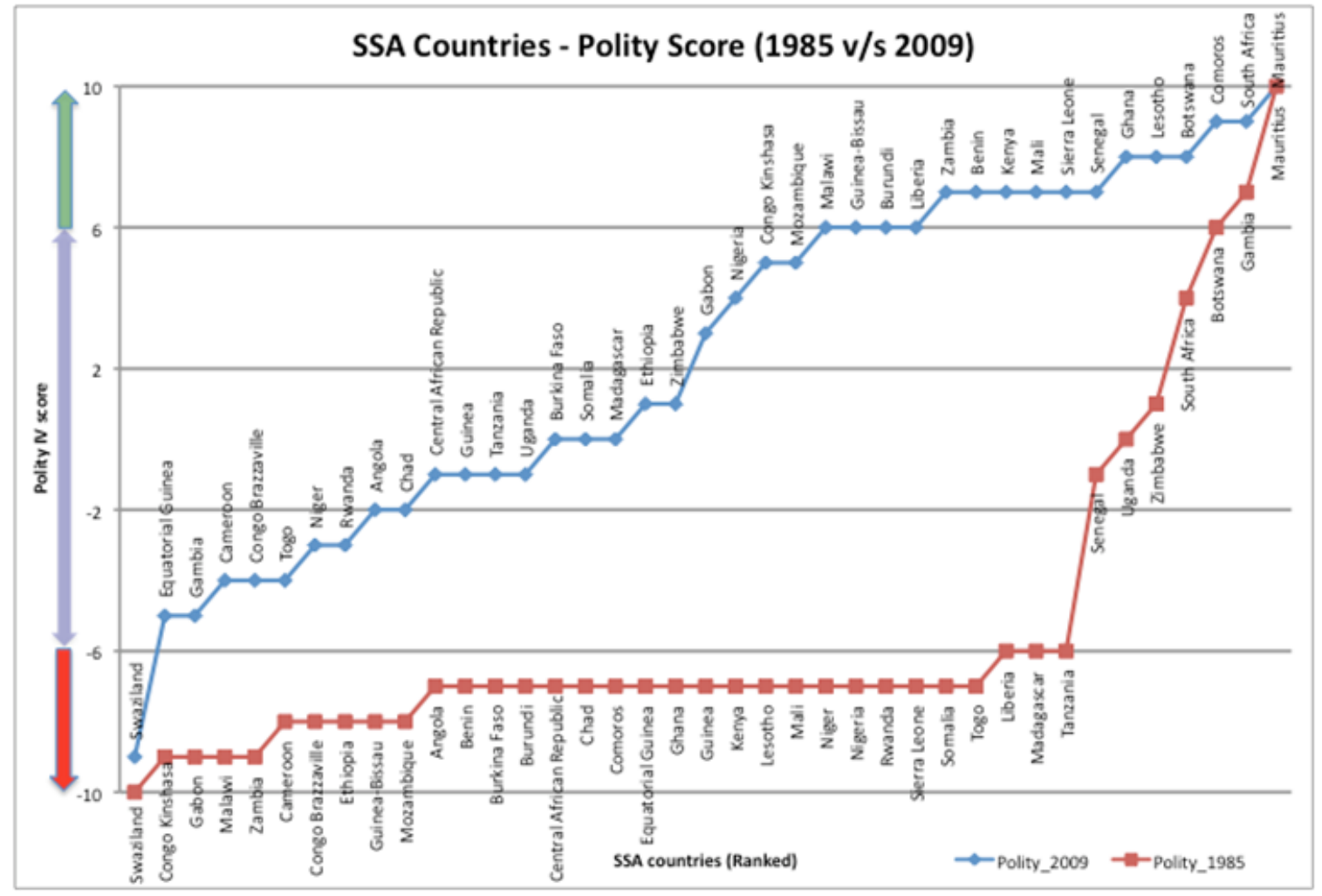

Source: Polity IV data base

The democratic wave has been shown to have large consequences for public policies. Harding and Stasavage (2011), for example, show that the transition to competitive elections in African countries is associated with the abolition of school fees, which in turn is associated with higher rates of school attendance than in nondemocracies. Kudamatsu (2011) finds in a sample of 28 African countries that infant mortality falls by 1.2 percentage points, which is 12 percent of the sample mean, after a country has experienced a change in political leadership through the winning of multiparty elections. However, this latter example also illustrates the limits of elections per se in addressing accountability failures-there is no evidence of systematic reduction in infant mortality in countries where an autocrat holds multiparty elections and stays in power by winning them. 
Even competitive elections can be influenced by violence, allegations of fraud, contestation of results, and are typically dominated by clientelistic practices of winning political support through promises of provision of private or group benefits (Keefer and Khemani, 2004). Such clientelist practices can have deep roots in historical institutions, as discussed in the previous section. Furthermore, there is also substantial variation in performance in growth and human development across autocratic regimes, which to a large extent overlaps the variation among democratic regimes (Besley and Kudamatsu, 2007). Autocratic and intermediate regimes can still be under political pressures to deliver on development to middle and poorer groups-as exemplified by countries such as Ethiopia and Rwanda that fall into this intermediate category.

A growing body of evidence on citizen participation in elections and other political processes in Africa is being generated through the use of the Afrobarometer surveys. ${ }^{9}$ Broad arguments are made on the basis of this data that citizen political behavior in Africa cannot be reduced only to responding to clientelist appeals and ethnic identity, but that performance of governments in managing the economy and delivering development matters as well (see for example, Bratton et al, 2011, and Young, 2009). Average self-reported voter-turnout in the 2008 round of the Afrobarometer survey for both "full democracies" and even intermediate cases, as rated by Polity IV, is higher than 70 percent (see Table 1, below). Such widespread intentions to participate in political processes likely encompass a variety of citizens, some of whom demand broad public services and economic development. In section 3 below we report evidence from experiments undertaken by civil society organizations in Africa to shift citizen demands away from clientelism and towards broad public goods.

\subsection{Accountability and civil society organization}

There also appears to be a large shift in Africa in organization among citizens. Village-level group formation in Africa increased dramatically over the 1990s when participatory approaches were emphasized in international development paradigms, promoted through aid, and adopted deliberately by country governments to deliver projects to communities. ${ }^{10}$ Bernard et al (2008), for example, show a rapid proliferation of village organizations (VOs) in a sample of

\footnotetext{
${ }^{9}$ Working papers using the Afrobarometer data can be found at http://www.afrobarometer.org/index.php?option=com_docman\&Itemid=39

${ }^{10}$ Here, we focus on community organizations intended to solve failures in the delivery of local public goods; instead of marketed-oriented organizations that have existed primarily in agriculture (Bernard et al, 2008).
} 
villages in Senegal and Burkina Faso between 1980 and 2002; in Senegal, by 2002, $65 \%$ of the sample villages had at least one VO (from 10\% in 1982); in Burkina Faso, $91 \%$ had one VO by 2002 (from 22\% in 1982). By 2002, 69\% of households in Senegal and 57\% in Burkina Faso were participating in some VO.

One of the concerns with donor-driven creation or funding of local groups is that it changes the nature of who participates most actively in these groups and to what ends. Arcand and Fafchamps (2008) find that members of externally funded organizations are more likely to be older and to have more land wealth. In a program in rural Kenya which provided leadership training and agricultural inputs to small self-help organizations, with mainly women members, Gugerty and Kremer (2006) find that membership in the groups selected for the program changed, with greater representation of the more educated, and those more likely to have formal sector income. That is, group membership and leadership moved into the hands of younger and better educated women, following the injection of external donor funding and programs. At the same time, perhaps surprisingly, the program showed unimpressive results in terms of productivity gains.

General theoretical treatments of civil society range from a "romantic" view of equitable participation in deliberative processes, in which rational argument resolves differing views and interest, to one in which civil society is viewed as essentially incorporating and perpetuating the unequal patterns of wealth, status, power and associated cultural practices within the overall society. ${ }^{11}$ Indeed, in the theory of public choice, the power of organized "special interests", that pursue their partisan objectives, has been blamed for distortions to growth-promoting or efficient or equitable fiscal policies even in the context of advanced industrial democracies, like the United States, (Tullock, 1959; Becker, 1985). An extreme and tragic example of conflict of interests within civil society in Africa is the Hutu mobilization (and the use of radio within this) in the Rwandan genocide.

The capacity for voluntary collective action, that is, the organization and exercise of action by civil society, is typically unequally distributed in a society. The issue is not simply one of whether the more poor and less educated are less likely to participate in organized groups (although a review of evidence from various countries by Mansuri and Rao, Forthcoming, suggests that can be the case), but a more complex one of how broader conditions of inequality influence how groups are organized and for what objectives. La Ferrara (2002) provides evidence from Tanzanian villages of

\footnotetext{
${ }^{11}$ See Baiocchi, Heller and Silva (Forthcoming, Chapter 1) for a review. The deliberative perspective is associated in particular with Jurgen Habermas, the view of civil society as reflecting and perpetuating inequalities with Pierre Bourdieu.
} 
such complex interaction between village-level inequality and group organization; perhaps most interestingly for our current discussion, in more unequal villages, individuals are less likely to report trust in the community, and more likely to report conflict of interest. There is more rigorous and detailed evidence from India on the role of historic institutions of inequality in influencing breakdowns in collective action for broad public goods (Banerjee and Iyer, 2005; Andersen, 2011), dissolution of social cooperation (Fehr, Hoff, et al, 2008), and weak performance of government poverty alleviation programs (Besley et al, 2004).

Ethnic fragmentation and polarization in many parts of Africa have been blamed for the lack of organization by civil society to generate political institutions in the public interest (Easterly and Levine, 1997; Alesina, Baqir and Easterly, 1999; Montalvo and Reynal-Querol, 2010). Miguel and Gugerty (2005) find that community contributions to public schools and quality of school infrastructure are lower in communities with greater ethnic diversity. In experimental work to examine why ethnicity matters in lowering contribution to public goods, Habyarimana et al (2007) conclude that it is not because of greater altruism towards co-ethnics, or greater sharing of common preferences, but rather because of greater power of social sanctions within ethnic networks. That is, social networks among co-ethnics make reciprocal exchanges easier to achieve.

Perhaps because it facilitates such reciprocal exchange, ethnic identity in Africa may be used to sustain clientelist political competition, enabling the type of quid-pro-quo interactions of provision of private benefits for political support that allow politicians to get away with larger rents and lower public goods. Consistent with this view of ethnicity as an instrument of clientelist strategies, Eifert et al (2010) find that self-reported ethnic attachment in the Afrobarometer surveys is greater when the question is asked nearer to elections.

Table 1 provides further data on reported participation in groups for 18 African countries covered by the most recent round of the Afrobarometer survey around 2008. On average, across all countries, 26 percent report being active members of a group, and 52 percent report frequently attending group meetings. Reported participation does not appear to be strikingly different across the countries classified as "full democracies" by Polity IV, versus those classified as "anocratic". Indeed, there is significant variation in group participation within these categories across countries. Among the full democracies, the highest ranking (South Africa and Botswana) have active group membership reported by only 16 and 17 percent, compared to a Kenya and a Liberia lower down the "democracy" scale, with 
43 and 45 percent respectively. Among the "anocracies", group membership and attendance in meetings is particularly high for Tanzania. ${ }^{12}$

The Afrobarometer data suggest that local-level organization of civil society into groups does not exclude the poor. For six countries-Benin, Botswana, Ghana, Senegal, South Africa, and Zimbabwe-an indicator of poverty in the Afrobarometer (when a respondent mentions that the household has gone without adequate food many times in the recent past) is significantly associated with greater attendance of group meetings (after controlling for respondent age, gender, education, media access, household size, and neighborhood availability of infrastructure). However, the extent to which these groups indeed represent the interests of the poor, or have impact on improved accountability for development outcomes are questions on which the evidence is patchy. This will be discussed in the following section. However, what can also be seen in the Afrobarometer data for seven countries-Benin, Lesotho, Mozambique, South Africa, Tanzania, Uganda, Zimbabwe-is that respondents that report going without food many times (an indicator of poverty) are significantly more likely to report fear of punishment or reprisals should they complain about poor quality of government services or misuse of government funds.

In five countries-Benin, Ghana, Senegal, Zambia, and Zimbabwe-respondents that report frequent attendance in group meetings are also more likely to be those with ethnic grievances. In these countries, ethnic grievance is also correlated with respondents reporting any instances of joining with others to raise an issue. Whether their participation in group and organized activities is geared towards broad collective action or narrower redress of ethnic grievances is an important concern for the efficacy of civil society action in addressing broad accountability failures.

These insights from research and evidence into local-level groups, and how their membership and leadership changes in response to the availability of external funding is pertinent for other donor initiatives to promote transparency and accountability through national groups and associations. We are not able to uncover any systematic evidence on the organization and incentives of such national civil society organizations. However, some types of activities undertaken by these groups have been subjected to rigorous impact evaluation in collaboration with independent researchers. The next section will discuss the state of evidence on

\footnotetext{
12 This is, in fact, quite visible during field visits to Tanzanian villages by one of the authors (Khemani) with posters listing village groups and their membership being plastered all over the walls of the village government office.
} 
particular types of interventions that could be undertaken by national groups to influence civil society organization to extract greater accountability.

Another interesting type of organization which could play a role, but again one on which we are not able to find systematic evidence in Africa, are business associations. As already emphasized, firms need a variety of public goods-most fundamentally the public good of credible commitments not to expropriate profits or assets once investments have been made-but also the provision of law and order, the underpinnings of contracts, a framework for labor relations and "real" public goods such as roads, ports, electricity networks and an education and training system that generates adequate skills. But both the general public good of credible policy commitment and specific public goods are hard to deliver (Haber et al, 2003).

Where these dilemmas are not resolved, the result is low levels of private investment and so low growth. This can also make a predatory policy, as opposed to a pro-development one, a more attractive political strategy. As discussed above, rent-sharing arrangements between political and business elites, with credible punishment for political elites in the event of reneging, are a solution to the commitment problem, but an imperfect one. And specific deals, for construction contracts, forestry concessions, mining production, the array of specific licenses needed for production and so on, are often obtained through personalized, corrupt transactions. Longer-term relations are based on the various forms of legal and illegal political finance.

This is where there is a potential role for business associations. On the one hand their function is to represent the interests of capital-and for society as a whole, there is a need for countervailing structures, such as trade unions, civil society groups or political representatives - to ensure that overall accountability is not skewed toward these interests. But they can also play a role in solving collective action problems within the business sector, both among large and small firms, and in pressing for states to deliver the general public goods for capitalist production as opposed to particularistic (and often corrupt) deals.

\section{Evidence on the impact of specific interventions}

Specific types of interventions have been pursued by civil society organizations, and supported by donors, to achieve incremental change within the broader systemic failures in accountability, both through addressing citizen participation in political processes and through citizen participation in monitoring and managing statefunded programs. This section focuses on assessing what the evidence tells us from 
interventions that have been rigorously evaluated, and identifying where there are large knowledge gaps compared to the theoretical potential examined in the analytical section. It makes selective use of some studies as examples, while referring to other comprehensive reviews that are available for broader conclusions. A literature review was also undertaken specifically for this paper, focusing on evidence generated through randomized control trials and other econometric methods for rigorous identification of impact, and classifying the interventions according to the arm of the accountability triangle at which they were aimed. ${ }^{13}$ This is appended to the paper.

Most of the interventions that have been carefully evaluated use some form of "information and transparency", not only to address information gaps among citizens, but rather to use more strategic packaging of evidence and advocacy to mobilize and persuade citizens to address accountability failures. That is, the interventions typically rely on a combination of all three types of mechanismsaddressing information gaps, mobilizing or coordinating citizens for collective action, and redressing weak sanctioning power.

\section{- Solving accountability failures in politics:}

“Open budget" initiatives. Making greater information available about government budgets has been at the center of many donor-supported civil society initiatives. Citizen action, and donor pressure on governments has contributed to the adoption of legislation for citizens' "Right to Information", and to various initiatives to facilitate citizen ability to monitor public budgets and allocation of public resources, such as the Extractive Industries Transparency Initiative, and the Open Budget Index. Descriptions of these initiatives, and reviews of evidence of their impact are provided by McGee and Gaventa (2010) and Gaventa and Barrett (2010). We classify these initiatives as addressing the "politics" arm of accountability between citizens and political leadership of states, geared as they are towards improving general accountability of overall state resource allocation.

Much of the evidence on how these initiatives work and what impact they have appears to be qualitative, and focuses on intermediate outcomes such as whether citizens indeed became more informed and engaged in budget processes. There are also some quantitative studies reviewed specifically in a background paper prepared by Carlitz (2010) for the synthesis report prepared by McGee and Gaventa (2010), that provide mostly cross-country correlations of indicators of greater budget transparency with indicators of governance, corruption, socioeconomic and human development, and even political participation. As with all such types of cross-country correlations, however, there is an important concern about causality-it is not possible to draw strong conclusions about whether specific budget transparency initiatives in fact lead to the better outcomes, or whether other underlying changes in government accountability to citizens drive the outcomes together. Micro-quantitative evidence of impact on budget allocations (which areas

13 This literature review was prepared by Avnish Gungadurdoss of the Harvard Kennedy School of Government. 
get more or less allocations), and budget implementation (whether the allocations translated into better services or outcomes) appears to be almost entirely missing.

There is evidence on a specific type of budget information which was pioneered in the education sector in Uganda. Purposefully designed survey instruments-named the Public Expenditure Tracking Surveys (PETS)—were used to measure discrepancies between budget allocations to schools in Uganda, and what actually reached the schools (Reinikka and Svensson, 2004). One study argues that the publication in mass media of estimated "leakage" in the flow of funds led to dramatic improvements, with most of the intended funds reaching the schools subsequent to the information campaign (Reinikka and Svensson, 2005). In this argument, accountability for the flow of funds improved because of addressing information gaps among parents in schools, and thus enabling them to exercise their client power vis a vis district authorities responsible for transferring funds to schools.

Following the celebrated success of the Uganda case there has been a proliferation of PETS activities, and external investments in strengthening the capacity of civil society organizations to undertake such surveys to uncover and publicize "leakage" and thereby stem it. More qualitative evaluations of these efforts suggest that they can be frequently successful in getting the funds to reach the intended destinations, although to a lesser degree than the estimates in Uganda (McGee and Gaventa, 2010).

However, alternate arguments about the drivers of success in the Uganda case indicate that the client-power channel was only part of the story. Hubbard (2007) examines larger changes in school funding policies in the Ugandan Ministry of Education, and suggests that the information that activated client-power may have been only one element in increasing the amount of resources available in schools; that other, perhaps larger, elements consisted of strengthening of the compact between the Ministry and the districts following President Museveni's 1996 election campaign in which free and universal primary education was a prominent agenda. This argument thus suggests that pressures working through the politics relationship led to a greater focus on education funding and to a better compact for education services. The role played by client power was a complement to changing political incentives within the state.

Are there other interventions that could enable civil society to influence the politics relationship to demand stronger changes in the compact? For example, the school grants covered by the PETS in Uganda are estimated to be a much smaller proportion of total government spending on education compared to teacher salaries (Hubbard, 2007). Other work on public education spending, and on the political economy of teacher management as a manifestation of clientelism, suggests that the compact with teachers is especially weak because citizens' demand from politicians for quality education services is not sufficiently strong. This takes us to evidence on information and communication campaigns to mobilize voters around broad public interest policies. 
Voter education: Can civil society engagement undercut clientelist politics, and better coordinate citizen demand for quality public services? A series of voter education experiments have been undertaken between CSOs and researchers in Benin, São Tomé and Príncipe, Mozambique, and Nigeria to reduce clientelism and violence in elections (Vicente and Wantchekon, 2008; Aker et al, 2010; Collier and Vicente, 2010).

In Benin, a civil society group organized town-hall meetings with real political candidates in the first round of the 2006 Presidential elections, to discuss specific policy proposals informed by empirical evidence (Wantchekon, 2009). The results of the impact evaluation suggest that where such town-halls were held, voter turnout was higher and support for clientelist political platforms was lower.

In São Tomé and Príncipe and Mozambique voter education campaigns were undertaken to persuade voters not to "sell" their vote. Previous work in São Tomé and Príncipe had documented that vote-buying practices increased dramatically in the late 1990s, after the discovery of oil (Vicente, 2010). Such practices have been analyzed as enabling political leaders to get away with large rents from public resources, while providing low quality and quantity of public services. In Nigeria, community campaigns were undertaken by civil society groups to encourage voters to oppose political intimidation or violence (Collier and Vicente, 2010). This body of work focuses on measuring impact on explicit political outcomes, such as voter turnout and use of different electoral strategies by incumbents and challengers.

There is also evidence from other regions, relevant for Africa, on voter education campaigns to reduce the extent to which citizens vote on the basis of ethnic identity (India) or gifts (vote-buying in the Philippines). Banerjee et al (2010) evaluate the impact of interventions by a CSO in India to persuade voters not to vote on the basis of caste identity of candidates; the results show that these were effective in increasing voter turnout and reducing the votes of caste-preferred candidates with criminal records. Schaffer (2005) provides qualitative evidence from the Philippines that voter education campaigns to reduce vote-buying practices may have unintended effects; that such campaigns may offend target groups and intensify "class divides" between the middle or upper classes that are the sponsors of the campaigns, and the poor, who are convinced of the legitimacy of receiving benefits from politicians in exchange for their vote.

While these are important examples of the engagement of civil society in strengthening political accountability by making elections more effective mechanisms for evaluating the policy performance of candidates, this body of work is not designed to examine the ultimate impact on policies and development outcomes. It is therefore not immediately clear whether even significant electoral effects of voter education campaigns would effectively translate into different or better policy choices. For example, if the campaigns primarily strengthen the hands of incumbent politicians (by reducing the efficacy of vote-buying tactics employed by political challengers), they may be further protected from the risks of losing office and able to continue rent-extraction policies. 
The example from the Philippines also suggests that tackling the proximate symptoms of clientelist political competition directly may not be effective. An alternate strategy, akin to the Benin town halls, could use information on policy performance to coordinate voters better on public goods platforms. Can policybased information and mobilization interventions overcome collective action problems (such as social polarization, ethnic fragmentation, and vote-selling), and weak sanctioning power (such as through state-led coercion and violence in elections)?

Politician and Constituency Report Cards: Civil society organizations in some countries have attempted to garner and provide information on performance of politicians in delivering benefits to their constituents. Banerjee et al (2010) evaluate the impact in India of providing information on the performance of state legislators in delivering constituency development projects and subsidized food rations to the poor. They find that greater information enabled voters to punish incumbents who performed poorly by voting against them in local elections. However, a similar experiment in Uganda with the African Leadership Initiative, providing information about the legislative activities of their MPs, and efforts towards spending their constituency development funds, seems to have had little or no impact on election outcomes (Humphreys and Weinstein, Forthcoming). Full results from Uganda are not currently available to assess whether greater performance information may nevertheless have contributed to improvements in legislator use of their funds, with the politicians changing their behavior in anticipation of electoral punishment. Keefer and Khemani (2009) find more qualitative evidence from India that a surge in media reporting about the lack of effort among MPs in using their constituency development funds was associated with dramatic increases in legislator effort and utilization of funds.

There is a new civil society effort underway in Africa, called Uwezo ${ }^{14}$, to measure education service delivery and learning outcomes on a large scale, enabling performance measures to be computed at disaggregated jurisdictional levels such as districts. Such disaggregated measurement could potentially enable attribution of performance in delivering education services to specific government agents and politicians. The Uwezo effort was partly inspired by a similar effort in India, called ASER (Annual Status of Education Report), run by the organization Pratham ${ }^{15}$. Although media stories would suggest that such initiatives contribute to strengthening political accountability for education outcomes, because of the information generated and collective pressure exerted by CSOs, there is as yet no rigorous evidence of how this changes key politically motivated distortions in education allocations. In the case of India, five years of ASER reports has played an important role in raising public awareness of the education quality, but has essentially found no overall increase in test scores for rural children in the period to 2010 (ASER 2011). There remains substantial untapped potential for examining whether such disaggregated information can indeed generate sufficient political

14 http://www.uwezo.net/

15 http://www.pratham.org/M-20-3-ASER.aspx 
pressure and yardstick competition across jurisdictions to improve performance (Khemani, 2007).

Brazil provides a qualitative example of successful experience with this type of information intervention, albeit one that was led by a "reformist" leader rather than by civil society organizations (Tendler, 1997). The Governor of the state of Ceará in Brazil, who took office in 1987, supported a strategy of creating a new class of public health workers through a publicized recruitment effort that conveyed information to communities about the valuable role the workers could play in improving public health through community-wide effort. The strategy also included extensive use of radio with messages about how infant and child mortality could be drastically reduced through particular programs of municipal governments, thus bringing political pressure to bear upon the mayors to actually deliver basic health services. In only a few years coverage of measles and polio vaccination in Ceará tripled to 90 percent of the child population, and infant deaths fell from 102 to 65 per thousand births. In addition to the specific health example, the state government leadership has been generally credited with using various means to bringing a remarkable turnaround in the municipal politics of the state-from clientelist and patronage-based to more service-oriented.

More recently, Brazil has been the source of another example of higher-tier government efforts to reduce local political rent-seeking by generating and providing credible information to citizens. In May 2003 the national government of Brazil launched an anti-corruption program based on the random auditing of municipal government expenditures by an independent public agency, and then publicly releasing audit findings on the internet and to media sources. ${ }^{16} \mathrm{New}$ evidence from more than 600 municipalities covered by the audit suggests that the disclosure of information significantly and substantially reduced the re-election rates of mayors who were found to be corrupt (Ferraz and Finan, 2006). Furthermore, this impact was significantly more pronounced in municipalities with greater access to radio stations.

What these examples suggest is the potential of particular types of information interventions that not only address information gaps, but also enable voter collective action and sanctions through greater coordination around the information. However, it is not clear that civil society organizations would be able to replicate the Brazilian success in the absence of leadership in some part within Government or through institutionalized state agencies.

An important question suggested by this for external donor assistance to civil society in Africa is whether performance information can be credibly generated and communicated in the way it was by the government of Brazil, and in ways that sustains the effects in between elections. Again, how would such information overcome the collective action problems posed by social polarization, ethnic

\footnotetext{
16 In Portuguese, this program is called Programa de Fiscaliza, cão a partir de Sorteios Públicos, details of which is available from the following website: www.presidencia.gov.br/cgu.
} 
fragmentation and vote-selling? Or of problems of weak sanctioning power of voters because of state-led violence and coercion in elections?

Mass media: The potential role of media organizations, such as radio, seems obvious as purveyors of information to large numbers of citizens, especially the poor. Indeed, donors have been engaged in setting-up and supporting community radio in various parts of Africa to broadcast public-interest programming for democratic values, human rights, and the importance of health and education. Yet, there is little rigorous evidence of their impact; recent work using new and unique data from Benin yields surprising conclusions for the advocates of community radio. Keefer and Khemani (2011a, 2011b) find that greater access to community radio in Benin is not associated with the ability of citizens to extract greater benefits from their government; instead, the impact of radio programming seems to be to persuade people to invest more of their own private resources into the education of their children and the health of their family. While this is a useful role for mass media to play in development, it is unrelated to the accountability challenge.

This contrasts with evidence from the post-Depression-era USA, when radio had just begun to spread, that greater access to radio enabled citizens to receive greater benefits from government welfare spending (Stromberg, 2004). It also contrasts with the experience from Uganda and elsewhere when media were used purposefully to disseminate information about leakage in public resources; in such cases they were instrumental in stimulating public opinion and action to reduce such leakage (Reinikka and Svensson, 2005, as discussed above). This suggests that investments in building capacity of media alone, and advocating their independence from the state, may not be sufficient to achieve greater accountability-investing further in well-designed messages, either those that can enable voters to coordinate on policy performance, or those that are endorsed by the state in an effort to improve efficiency in its public spending (as in the Brazil examples discussed above) is needed.

Although theory suggests an accountability role for mass media, it also suggests that media could be used for political "posturing" and "pandering", reducing incentives to pursue actions that contribute to broad public goods. (Prat, 2005; Besley and Prat, 2006; Mullainathan and Shleifer, 2002; Maskin and Tirole, 2004). For example, when there is uncertainty about the effects of different policies, and policymakers/politicians as "experts" have access to greater private information about these different effects than do voters, media coverage may induce politicians to take positions that cater to voter beliefs, ignoring their private information that could lead to better policy decisions.

The policy mantra for media development for accountability seems to be to pursue laws and regulations for media independence from state control, which while probably necessary doesn't address other incentive issues in competitive media markets. First, even independent media may be manipulated by governments seeking to broadcast propaganda messages, or because politicians service the partisan interests of media owners - that is, independent media can be "lapdogs" rather than "watchdogs"(Qian and Yanagizawa, 2010). Second, media have 
incentives to "slant" the news to cater to people's priors, instead of reporting unbiased information. Recent empirical estimates of the large effects of radio on violence in Rwanda, concluding that "hate radio" may explain as much as 9 percent of the genocide (Yanagizawa, 2010), is a singularly dramatic demonstration of a general proposition that media effects are contingent upon the messages and programming broadcast, which depend on larger political incentives and biases and prejudices among citizens.

The conventional wisdom on the drivers of the recent Arab Spring indicates that citizen collective action on such a large scale was facilitated by social media and information and communication technology (ICT). Indeed, pioneering efforts such as Ushahidi17, to develop platforms for "crowd-sourced" information have their roots in Africa, with much enthusiasm that such technological advances can have far reaching accountability effects by spurring collective action among citizens. Again, however, there is little rigorous research on whether or how ICTs enable greater public accountability. Most of the work on ICT, accountability and transparency, remains at the level of assuming that greater use of and investment in such technology are both necessary and sufficient, with little or no work investigating what kinds of accountability messages or interventions, delivered through ICT, do or don't achieve impact on development effectiveness. There is substantial scope for pursuing such a research program, which may have especially large returns in terms of reaching the pivotal "youth" group for democratic political stability that is conducive to good economic policies.

The question for external support to citizen media and ICT organizations, once again, is whether such support can promote information for development and public interest accountability. There is little knowledge of what does or does not work in using media and ICT to promote accountability for development effectiveness. Addressing this knowledge gap requires a program of rigorous, databased impact evaluation, rather than simply greater advocacy for greater media independence and transparency. What accountability or governance interventions facilitated by media can improve the quality of public services? Do media help to make public-payroll teachers show-up and teach in schools? Do they improve the implementation of public health programs? Can media do this only through the strengthening of compact and client power by "willing" state agencies; or, can it address the more fundamental political constraints to weak compacts and client power in the first place? What types of intervention design can overcome potentially harmful civil society action along ethnic lines?

\section{- Solving accountability failures in compact and client power:}

A wide range of interventions have been pursued by governments and donors in engaging civil society in local communities to monitor and directly participate in the delivery of public services. Some of the initiatives of civil society organizations, such as Uwezo and ASER, discussed above as information interventions that potentially influence politically accountability, may indeed not be

17 http://www.ushahidi.com/ 
primarily described by their organizations as such, but rather more about community mobilization and engagement to take direct action to improve public services.

Citizen Report Cards: The experience of a CSO based in Bangalore, India, the Public Affairs Centre, in pioneering the use of "citizen report cards" as a tool for client power has been celebrated in much of the development policy literature. In the anecdotal evidence provided by Paul (2002), this initiative aggregated citizen perceptions of the quality of urban services provided by various agencies in the city of Bangalore, then publicized these through local media, serving as a massive, collective complaint mechanism. This either "shamed" the agencies into improving services, or sent a strong signal to local municipal politicians that citizens care about service delivery and the politicians in turn put pressure on the providers to improve performance. Subsequent surveys by the same CSO report substantial improvements in perceptions of service over time.

However, there are diverging results from more rigorous evaluation of such initiatives in rural areas of India and Africa (Uganda). In Uganda, Bjorkman and Svensson (2006) report on interventions in 25 communities where local CSOs organized meetings between community members and health service providers of public clinics around citizen report cards on the quality of care provided at these clinics. Compared to "control" communities where no such discussion took place, in intervention communities both provider attendance and quality of service measures (including wait time and quality of care) improved. The final result was an increase in the immunization rate and a substantial drop in child mortality in the communities where the mobilization interventions occurred. The evidence suggests that these improvements in health services resulted from greater activism by the community in monitoring health clinics and demanding improvements, most likely through existing beneficiary-control institutions called Health Users Management Committees (HUMCs). This is a case in which information, and possibly complementary mobilization, activated a client power mechanism that the state has already set up.

However, similar meetings that were organized by a CSO (Pratham, mentioned earlier) in India around citizen report cards on the quality of education services in 195 intervention villages had no impact on teacher effort, or on learning outcomes in public schools (Banerjee et al, 2010). The intervention also had no impact on a beneficiary-control institution existing in the state (Uttar Pradesh) where the study was conducted-the Village Education Committee (VEC), which is authorized by the state and in principle operates much like the HUMCs for health services in Uganda. In both UP and Uganda these existing institutions were found to be inactive at the baseline.

Yet, perhaps the most striking finding of the India study is that in one set of intervention villages, where the citizen report card was combined with an offer by Pratham to train village volunteers to hold remedial classes outside school, a large number of local youths volunteered to hold such classes, completely bypassing the public school system. In these villages, the children who attended the volunteer-led 
remedial classes made dramatic improvements in learning. Better information here induced greater private efforts, by the volunteers and the families of the children. Such instances of direct citizen participation are of course inspiring, but leave open a billion-dollar question (in the context of public spending on education in India)how to make the substantial allocation of public resources to education less wasteful and more effective in delivering development ? These villages in north India were able to take private collective action to help themselves, facilitated by the CSO Pratham, but were not able to overcome the barriers to holding local politicians and bureaucrats to account for the large amounts of state resources going to salaries of absent teachers and captured school construction.

Furthermore, the results of the participatory interventions documented in Banerjee et al (2010) contrasts with those of another information intervention in similar villages in the same part of north India which was not as participatory but rather carried the seal of the state department of education, and was delivered through a savvy video played to village gatherings (Pandey et al, 2009). This resulted in the village public school teacher reducing absenteeism, with some discernable effects on improvements in learning among children.

Such large variation both within and across different information interventions to mobilize citizens to increase their client power suggests that local context and the larger political economy environment matter significantly for success, especially in supporting (or not) citizen engagement in strengthening compacts or authorized client-power structures with public providers.

A rigorous impact evaluation of another type of client-power initiative to combat corruption in local infrastructure construction projects was able to directly contrast the efficiency of citizen-led initiatives with other technocratic means of strengthening the compact between the state and local providers. In Indonesia, Olken (2005) compared the impact of information provision to local citizens about corruption in local roads projects against that of a technocratic government-led initiative-credible audits of local projects by higher tier authorities. He finds that the state-led audits were substantially more effective at reducing corruption than the intervention based on information and local collective action. Another study, in Madagascar, contrasting interventions designed to encourage district education bureaucrats to improve their monitoring of schools, versus directly engaging school communities to do so, instead finds that local-level monitoring was more effective (Nguyen and Lassibille, 2008). However, in contrast to the certain-audit intervention in Indonesia, the Madagascar intervention did not require district officials to improve their monitoring.

Community "management" committees: There are a large number of initiatives pursued by governments and donors to organize citizens in local communities into committees to manage environmental resources, targeting of benefits of poverty alleviation schemes, infrastructure projects, health and education services (as in the cases of HUMCs in Uganda and VECs in India described above). In an extensive 
review of the evidence of the impact of such initiatives, Mansuri and Rao (Forthcoming), conclude that there is variation in the success of such initiatives which depends on the nature of social organization across communities (the degree of inequality, in particular), the technical complexity of projects, and importantly, on whether higher-tier state agencies indeed provide the powers and resources to local committees to be effective. That is, these initiatives can serve to strengthen clientpower and/or compact, as long as they are appropriately designed and supported to do so by higher state agencies, and as long as collective action processes within communities can work.

Participatory budgeting: Participatory budgeting, another initiative popular with donors and some governments to engage civil society to address accountability problems, where citizens directly participate in formulating budgets of local governments, was pioneered in the city of Porto Allegre in Brazil, where the city council devolved decision making over new capital investments to citizen councils. This devolution has been credited in qualitative analysis with substantial improvements in local governance and responsiveness to the needs of the poor, although there is a problem in attributing gains to the institution of participatory budgeting. The introduction of participatory budgeting in Porto Allegre went handin-hand with the election of a particular political party (the Partido dos Trabalhadores, or Workers Party) which catered to a particular constituency of citizen activists (and therefore adopted a specific mode of participatory institutions to implement its compact) and had broader incentives to service the poor.

Baiocchi et al (2011) use a regression discontinuity empirical design to address the possible conflation of the political effects of voter support for the Partido dos Trabalhadores with the use of the institution of participatory budgeting-they compare outcomes across municipalities where the party won or lost the elections by a narrow margin. These municipalities are therefore similar in voter support for the party, but in only one set, where the party won narrowly, was participatory budgeting adopted by the municipality. They report differences in the process of citizen engagement with the local government, but do not examine impact on outcomes of service delivery or poverty reduction. Further, they conclude that even the impact on greater inclusion of citizens in government decision-making is conditional on pre-existing state-citizen relationships, that is, on the political relationship.

Community-driven-development (CDD) projects. Several communitydriven-development (CDD) projects "bundle" different interventions that potentially impact each arm of accountability: they change the compact by transferring funds/project management from line ministries to local governments or to newly created local agencies with direct citizen representation (such as school committees); they change client power by allowing such agencies of citizen representation some power over service providers; they change politics by increasing the representation of some groups (women, youth, traditionally marginalized social groups) whose participation in political processes could impact 
broader political incentives; they also change politics by attempting to increase social cohesion for greater collective action.

Again, drawing upon the extensive review of such projects in Mansuri and Rao (Forthcoming), the broad conclusion is that while citizen participation in project design and implementation can have beneficial effects on project outcomes (better design, better quality, better targeting of benefits to the poorest), this varies across communities with variation in characteristics of initial inequality, social cohesion, and state-citizen relations (politics). Furthermore, in the available evidence, there has been little scope to test whether there is any impact on political inclusion of marginalized groups and social cohesion, leading to effects on the politics relationship that could extend beyond the project.

Two more recent pieces of work that have attempted to examine impact on political accountability, through broader political inclusion and social cohesion, reach different conclusions. Casey et al (2011) conclude from the detailed examination of a CDD program in Sierra Leone that although it improved local public goods provision and household welfare in the short-run (which could be because of the increased funds provided), there was no long-term or durable impact on local institutions of decision-making, inclusion, and collective action. In contrast, Fearon et al (2009) find in Liberia that a CDD project did not have significant impact on local household welfare measures, but that in project villages the results of behavioral games played with community members indicates greater social cohesion and willingness to contribute to public goods.

Community-driven reconstruction in post-conflict settings. The two studies just referenced are examples of particular types of CDD projects with the broader aim of providing benefits to the poor and building social cohesion in postconflict environments. Once again, a broader review of the evidence of such forms of engaging civil society, both to deliver project benefits and to address the root causes, perhaps, of conflict, concludes with strikingly mixed messages (Mansuri and Rao, Forthcoming). While there are some qualitative cases of success in both delivering benefits to the poor and to ex-combatants, and in engaging civil society to confront violent actors, others find that the poor and marginalized find it even harder to access project benefits in conflict areas, and that governments only selectively scale-up such projects in areas where they command political support. The authors of the positive outcomes measured in Liberia, Fearon et al (2011), point out that their results may not speak to addressing conflict per se, because conflict usually occurs at higher levels than that of the local "community" targeted by CDD/CDR projects. It is even possible that strengthening cohesion within communities may worsen conflict across communities.

In sum. Interventions that organize civil society to improve the compact and client-power can be effective; however, much depends on project design and initial conditions of inequality and social cohesion that vary across communities. This does not imply that community participation in projects involving public goods will always fail in communities with high levels of inequality or weak social cohesion (low "social capital). Khwaja (Forthcoming) finds that modifying project design can 
compensate for such features of local communities in his analysis of communitymaintained infrastructure in Northern Pakistan. In particular, reducing project complexity and confining community participation to non-technical aspects of maintenance improved outcomes in "social adverse" settings; moreover, projects initiated by communities and NGOs had much greater success than those started by governments. That is, much depends on whether political relations are sufficiently strong to give incentives to governments to select good project design, tailored to community conditions.

More broadly, however, it is almost never possible to make a general statement that civil society engagement is more effective than technocratic changes to the compact between governments and their local agents, bureaucrats and public providers. Even when governments allow (driven by donor or NGO pressure) or elect to undertake projects that engage civil society, they may continue to let their bureaucrats and providers get away with high salaries and low effort in servicing citizens, especially the poor. There has been little scope to test whether participatory interventions at the local level have impact on civil society capacity for demanding accountability outside the narrow scope of specific projects; in the few cases where such testing is possible, there is no evidence of impact outside the project. This pattern of evidence lends itself to a general concern with community participation, that is also expressed in Banerjee and Duflo (2008), that the responsibility for managing successful projects is being palmed-off to largely poor communities, and could be viewed as a tax on their time and efforts; as opposed to other modalities of improving accountability of government agents to work harder and better for the poor.

Evidence is particularly lagging on the potentially central domain of how civil society could solve accountability problems in politics and thereby strengthen incentives of higher-tier governments to pursue appropriate interventions for improved compact and client power. For example, there is little rigorous impact evaluation of the role of mass media and cutting-edge communication technologies, that are proliferating across Africa, and being credited in the conventional wisdom with strengthening political accountability; on the contrary, available evidence provides sobering conclusions that media can be either ineffective or even tragically misused. Such large evidence gaps have implications for external aid strategies in supporting civil society in Africa to address accountability failures.

\section{Accountability, civil society and external donors}

Should external donors support civil society to tackle accountability problems in African states? Is this a route to improving delivery of public goods, whether for poverty reduction, human development or dynamic business investment? The analysis of this paper indicates that such action, while surely desirable, is fraught with both difficulties and uncertainties-difficulties because of the intrinsic problem of an external actor seeking to change a socio-political system, and uncertainties because of the weak information on what does and does not work. 
There is a case for external action, but the intervention needs to be designed in ways that takes account of these constraints, with a particular emphasis on a process of discovery and experimentation of what works.

In the core aid community there has been extensive interest in areas related to accountability since the mid-1990s, with activities supporting "governance" and community-driven development (CDD), as well as a longer tradition of support for various aspects of institutional development. The history is cautionary with respect to actual results. For example, reviews of the impact of World Bank support for public sector reform suggest mixed results at best. While there have been some highly celebrated CDD programs (e.g. the Self-help group movement in India), actual evidence of major change is also weak, as indicated in the review of evidence above and other more extensive reviews (Mansuri and Rao, Forthcoming). In this paper we suggest that ignoring the underlying political economy drivers of accountability may have been a principal factor accounting for cases where results were less than satisfactory.

First, aid for improved accountability improvements will get lost within a generalized clientelistic or predatory state system, whether the aid is attempting to improve public administration against the grain of the underlying incentives and organizational culture, or supporting small local islands of client power.

Second, aid can often be a source of distortions within the system, especially when it is large in scale (as it is in many African countries). Of course, aid is generally trying to change parts of the system, but it all too often has an inadequate theory of change, and becomes a source of unintended, adverse consequences. Support for "civil society" is just as likely to be distortive as accountability-improving, if it is illdesigned.

Third, aid for civil society can become a basis for new breeds of rent-seeking NGOs complete with mutually agreeable new narratives, just as African counterparts in the 1980s and 1990s learnt the language of structural adjustment, even while the aid was going into a still highly clientelistic system.

Our review of the evidence-that includes a significant proportion of aid-supported initiatives - shows that our current state of knowledge of just how externally supported action interacts with civil society initiatives is very weak, both because many results are limited and ambiguous, and also because most results are for local islands of action, with unusually large uncertainties over scalability.

\section{Some practical implications}

The analysis of this paper presents a difficult challenge: it develops the case for systemic change, while showing the difficulty of external aid initiatives' doing this successfully (and not making things worse) and the lack of clear evidence on what does work. To resolve this challenge, we suggest some principles that external 
donors can apply in ensuring that their interventions in supporting civil society to strengthen accountability will lead to an improvement.

In general, aid is most likely to be effective if it essentially organic, in the sense of (a) supporting existing domestic initiatives and pressures for change, and (b) in ways that are consistent with the initial state of the polity. The latter is likely to vary significantly across countries. This suggests a procedural case for linking external support with diagnosis of the institutional functioning of a country, sector, region or wherever the focus of desired action is.

In addition there are a number of areas where there is a good prima facie case for support, provided the general conditions apply. This will typically be a function of the nature of overall polity. For example, there is the largest range of potential action for democracies with real political competition, albeit of a competitive clientelistic form, whether the regime is consolidated or fragile. Here are some categories.

- There is a strong case for general support on information-related initiatives-from information on politician performance, to school test results, procurement processes and so on.

- There is also a contingent case for support for local organizational initiatives that are working with and processing information that the evidence base suggests has potential in solving accountability problems. This is related to the broad point that citizens and state actors do not need full information, but information salient to specific aspects of performance assessment. This domain can include NGOs working with right-to-information laws, think tanks analyzing budgets or regulator behavior, or service delivery outcomes, etc.

- A related area concerns support for information for benchmarking of performance of local levels of government, e.g. municipalities; or across local service providers (schools; electricity and water supply), where service quality can be measured and compared

- It often makes sense to support local client-power-related initiatives, but these are only likely to be fruitful if linked to broader change over the long route.

- Support for the strengthening of compact mechanisms is highly desirable if this has domestic political and technical support.

- There are two kinds of roles for civil society in the business sector. 
- Support for processes that provide mechanisms for both identifying and resolving conflicts between business investment and social and environmental concerns, especially in mining and urban development.

- Support for business associations working for public goods for business, e.g. agencies such as IFC that are concerned with private business, with the important concern that this needs to take account of conflicts of interest in aid, since such agencies are also often engaged with particular investment projects and firms.

Finally, in all cases, there is a need to base any support in an analysis of the nature and functioning of civil society. As has been emphasized here, and as sociologists have also argued, civil society can be a force for pressuring the state to be more responsive to citizens and more equitable, or can be a source of exclusion and the reproduction of inequalities (Baiocchi, Heller and Silva, 2011). Civil society will also typically work very differently under more and less democratic regimes.

In general, aid should not be focused on "money". This can be counter-productive (for reasons mentioned above). Rather, external partners can provide technical assistance in designing locally-grown interventions; they can play a role in financing information-gathering by local NGOs (e.g. Pratham and ASER); and can finance experimental interventions (and their learning). Most valuable is likely to be support for a domestic process of innovation and learning involving a generalized approach of experimentation — of which RCTs are one, but only one, component.

Can aid ever lead to transformational changes in accountability relations? Almost certainly not, if designs are hatched and brought in from outside. However, aid can potentially provide a supporting role if it is aligned with the flow of internal initiatives, is consistent with domestic political strategy, and supports greater accountability at the margins of major projects. Our analysis supports the view that recognition of the systemic features of state behavior is fundamental to interpreting the development process. An aspiration to effect some form of system change is admirable, for both internal and external actors. But for donors this needs to be blended with humility over the limits and unintended consequences of external action, and a central focus on helping domestic actors learn by doing.

\section{Conclusion}

This paper has reviewed the potential role of civil society action in increasing the accountability of the state for development in Sub-Saharan Africa. It has focused in particular on the question of whether states can be induced to more effectively deliver the broad range of public goods needed for development, from credible policy commitments for business to universal quality education. It has argued that this question has to be understood in the context of the overall political economy of African societies, and the way in which civil society is constituted and functions. 
There has been substantial change in African polities in the past two decades, with fewer totally despotic states, a remarkable expansion in democracy, and fewer countries mired in internal conflict. But most states remain deeply clientelistic, or personalistic, or riven along identity lines. State apparatuses typically have weak internal accountability mechanisms, and are sometimes predatory on the citizens. Democratic countries are typically characterized by "competitive clientelism". Many countries hold elections but are still intermediate, semi-authoritarian regimes. Africa is by no means unique in these respects.

We have argued that there is a potential role for civil society action in these contexts. The most important domain for greater accountability is via power and politics. If politicians, and especially leaders, do not have the incentives to deliver on development, putting extra pressure on bureaucratic state agencies is likely to have limited, or local effects. When the political leadership has some commitment to development, civil society may have a role to play in how internal state mechanisms work, including in front-line interactions.

However, civil society actors are themselves part of unequal societal structures, in terms of the capacity for collective action, the potential to influence the state, and the extent to which they seek to further general development goals. The variation in civil society is important to both understanding and designing its role in increasing accountability. Moreover, whether civil society engagement will be effective will also depend on whether there is salient information on state performance, resolution of collective action issues among citizens, and on the existence of effective sanctions. With the partial exception of very local interactions (and violent or peaceful revolutionary changes), immediate sanctions will depend on the activation of complementary within-state accountability mechanisms.

The review of evidence on specific civil society interventions further underlines the conclusion that effects will be uncertain and contingent. While there are a large number of potentially valuable initiatives underway, only relatively few have been carefully evaluated, especially in the domain of politics, and results have been mixed.

The implication is that generalized, "best practice" initiatives for greater civil society engagement are likely to fail. There is a strong prima facie case for greater action, but it is important that this be both organic-building on existing political and civil society structures-and experimental-structured for careful monitoring and assessment of how interventions work in practice and their impact. This applies with particular force to the strategies and support provided by external actors. 


\section{References:}

Acemoglu, Daron, Stephen Gelb and James A. Robinson. 2007. "Black Economic Empowerment and Economic Performance in South Africa." Cambridge, MA: Center for Economic Development, Working Paper.

Acemoglu, Daron and James A. Robinson. 2006. Economic Origins of Dictatorship and Democracy. Cambridge, UK and New York: Cambridge University Press.

Acemoglu, Daron and James A. Robinson. Forthcoming. Why Nations Fail. Book manuscript.

Acemoglu, Daron, Simon Johnson and James A. Robinson. 2001. "The Colonial Origins of Comparative Development: An Empirical Investigation." American Economic Review 91 (2001): 1369-1401

. 2005. "Institutions as a Fundamental Cause of Long-Run Growth." Handbook of Economic Growth 1A : 386-472.

Aker, Jenny, Paul Collier and Pedro Vicente, 2010. "Is Information Power? Using cell phones during an election in Mozambique," Working Paper, Department of Economics, Oxford University

Alesina, Alberto, Reza Baqir and William Easterly 1999. "Public Goods and Ethnic Divisions.” Quarterly Journal of Economics. 114(4): 1243-1284

Anderson, Siwan. 2011. "Caste as an impediment to trade," American Economic Journal: Applied Economics, 3(1): 239-263.

Andrews, Matthew. 2008. "Is Black Economic Empowerment a South African Growth Catalyst? (Or Could it Be?)." Center for International Development Working Papers and HKS Faculty Research Working Paper Series (170 and RWP08-033), June 2008.

Arcand, Jean-Louis and Marcel Fafchamps. 2008. "Matching in Community-based Organizations," Working Paper, Department of Economics, University of Oxford

Azam, Jean-Paul. 2001. The Redistributive State and Conflicts in Africa Journal of Peace Research, 38(4): 429-444

Baiocchi, Gianpaolo, Patrick Heller, and Marcelo K. Silva. 2011. "Bootstrapping Democracy: Transforming Local Governance and Civil Society in Brazil" Stanford: Stanford University Press.

Banerjee, A., R. Banerji, E. Duflo, R. Glennerster, and S. Khemani, 2010. "Pitfalls of Participatory Programs: Evidence from a randomized evaluation in education in India," American Economic Journal: Economic Policy, 2(1): 1-30. 
Banerjee, A., D. Green, J. Green, R. Pande. 2010. "Can voters be primed to choose better legislators? Experimental evidence from rural India," Working Paper, Kennedy School of Government, Harvard University

Banerjee, A., S. Kumar, R. Pande and F. Su. 2010. "Do informed voters make better choices? Experimental evidence from urban India," Working Paper, Kennedy School of Government, Harvard University

Banerjee, Abhijit, and Lakshmi Iyer. 2005. "History, Institutions and Economic Performance: The Legacy of Colonial Land Tenure Systems in India," American Economic Review, 95. 1190-1213.

Becker, G. S. 1985. "Public policies, pressure groups and deadweight costs," Journal of Public Economics, 28: 330-47.

Bernard, T., M. Collion, A. de Janvry, P. Rondot, and E. Sadoulet. 2008. “Do village organizations make a difference in African rural development? A study for Senegal and Burkina Faso," World Development, 36(11): 2188-2204.

Besley, Timothy and Masayuki Kudamatsu, 2008. "Making Autocracy Work" in Elhanan Helpman (ed.) Institutions and Economic Performance. Cambridge, MA: Harvard University Press.

Besley, Timothy, Rohini Pande, and VijayendraRao. 2004. "The Politics of Public Good Provision: Evidence from Indian Local Governments." Journal of the European Economic Association 2 (2-3): 416-26.

Besley, T. and A. Prat, 2006, Handcuffs for the Grabbing Hand? Media Capture and Government Accountability. American Economic Review 96, 720-720.

Bjorkman, M. and J, Svensson. 2006. "Power to the People: Evidence from a Randomized Experiment of a Community Based Monitoring Project in Uganda." Mimeo. IIES, Stockholm University

Bratton, Michael, Robert Mattes and E. Gyimah-Boadi, 2005. Public Opinion, Democracy and Market Reform in Africa. Cambridge, UK and New York: Cambridge University Press.

Bratton, Michael, Ravi Bhavnani and Tse-Hsin Chen, 2011. "Voting Intentions in Africa: Ethnic, Economic or Partisan?” Afrobarometer Working Paper No. 127

Carlitz, R. 2010. "Background paper on budget processes," Prepared for the Review of Impact and Effectiveness of Transparency and Accountability Initiatives. Brighton, UK: Institute of Development Studies.

Casey, K., R. Glennerster, and E, Miguel. 2011. "Re-shaping Institutions: Evidence on external aid and local collective action," Working Paper, Department of Economics, University of California-Berkeley 
Chandra, Kanchan. 2004. Why Ethnic Parties Succeed: Patronage and Ethnic Headcounts in India. Cambridge and New York: Cambridge University Press.

Chaudhury, Nazmul; Jeffrey Hammer, Michael Kremer, Karthik Muralidharan, and F. Halsey Rogers. 2006. "Missing in Action: Teacher and Health Worker Absence in Developing Countries," Journal of Economic Perspectives, Winter 2006, pp 91116.

Collier, Paul and Pedro Vicente, 2010. "Votes and Violence: Evidence from a field experiment in Nigeria," Working Paper, Department of Economics, University of Oxford

Easterly, William and Ross Levine. 1997. "Africa's Growth Tragedy: Policies and Ethnic Divisions," Quarterly Journal of Economics, 112(4): 1203-1250.

Eifert, B., E. Miguel, and D. Posner. 2010. "Political competition and ethnic identification in Africa," American Journal of Political Science, 54(2): 494510 .

Engerman, Stanley L., and Kenneth L. Sokoloff, 1997. "Factor Endowments, Institutions, and Differential Paths of Growth Among New World Economies: A View from Economic Historians of the United States," in Stephen Haber, ed., How Latin America Fell Behind 260-304. Stanford, CA: Stanford University Press, 260-304.

Fearon, James, Macartan Humphries, and Jeremy Weinstein. 2009. "Can development aid contribute to social cohesion after civil war? Evidence from a field experiment in post-conflict Liberia," American Economic Review: Papers and Proceedings, 99(2): 287-291.

Fehr, Ernst, Karla Hoff and Mayuresh Kshetramade. 2008. "Spite and Development," American Economic Review: Papers and Proceedings, 98(2): 494-499.

Ferraz, C. and F. Finan. 2008. "Exposing Corrupt Politicians: the effect of Brazil's publicly released audits on electoral outcomes," Quarterly Journal of Economics, 123(2): 703-745.

Gauthier, Bernard and Waly Wane. 2008. "Leakage of Public Resources in the Health Sector: An Empirical Investigation of Chad," Journal of African Economies, July, 10.1093.

Gaventa, John and Gregory Barrett. 2010. "So what difference does it make? Mapping the outcomes of citizen engagement," IDS Working Paper 347, Institute of Development Studies, Sussex

Gugerty, Mary Kay and Michael Kremer. 2008. "Outside Funding and the Dynamics of Participation in Community Associations." American Journal of Political Science 52(3):585-602 
Haber, Stephen H., Armando Razo and Noel Maurer. 2003. The Politics of Property Rights: Political Instability, Credible Commitments and Economic Growth in Mexico, 1876-1929. New York: Cambridge University Press.

Habyarimana, James, Macartan Humphreys, Daniel N. Posner and Jeremy M. Weinstein. 2007. "Why does ethnic diversity undermine public goods provision?" American Political Science Review, 101(04): 709-725.

Harding, Robin and David Stasavage. 2011. "What Democracy Does (and Doesn't) Do for Basic Services: School Fees, School Quality and African Elections," Working Paper, Department of Politics, New York University

Hubbard, P. 2007. "Putting the power of transparency in context: Information's role in reducing corruption in Uganda's education sector," Working Paper No. 136, Center for Global Development, Washington DC

Humphreys, M. and J, Weinstein. 2010. Policing politicians: citizen empowerment and political accountability in Uganda. Mimeo. Columbia University, Department of Political Science

Keefer, P. and S. Khemani, 2011a. "Mass Media and Public Services: The Effects of Radio Access on Public Education in Benin," Policy Research Working Paper Number 5559, Development Research Group, The World Bank

Keefer, P. and S. Khemani, 2011b. "The Role of Mass Media in Poor Democracies: Impact of Radio on the Distribution of Anti-Malaria Bed-nets in Benin," Mimeo, Development Research Group, The World Bank

Keefer, P. and S. Khemani, 2009. "Why do some legislators pass on "pork"? The role of political parties in determining legislator effort," American Political Science Review, 103(1): 99-112.

Keefer, Philip and Stuti Khemani. 2005. "Democracy, Public Expenditures, and the Poor: Understanding Political Incentives for Providing Public Services." World Bank Research Observer. 20 (1): 1-28.

Keefer Philip and Razvan Vlaicu. 2008. "Democracy, Credibility and Clientelism," The Journal of Law, Economics, and Organization," 24(2): 371-406.

Kelsall, Tim. 2002. Shop windows and smoke-filled rooms: governance and the repoliticisation of Tanzania. Journal of Modern African Studies 40 (4):597-620.

Khemani, Stuti. 2007. “Can Information Campaigns Overcome Political Obstacles to Serving the Poor?" In The Politics of Service Delivery in Democracies: Better Access for the Poor, Shanta Devarajan and Ingrid Widlund (Eds.), Expert Group on Development Issues, Ministry for Foreign Affairs, Sweden, 2007 
Khwaja, Asim Ijaz. Forthcoming. Can Good Projects Succeed in Bad Communities? Forthcoming, Journal of Public Economics.

Kingdon, G. and M. Muzammil. 2001. "A Political Economy of Education in India," Economic and Political Weekly, 36(32): 3052-3063

Kitschelt, Herbert and Steven I. Wilkinson. 2008. Patrons, Clients and Policies. Patterns of Democratic Accountability and Political Competition. Cambridge and New York: Cambridge University Press.

Kudamatsu, Masayuki. 2011. "Has Democratization Reduced Infant Mortality in SubSaharan Africa? Evidence from Micro Data." Forthcoming in Journal of the European Economic Association

La Ferrara, Eliana. 2002. "Inequality and group participation: theory and evidence from rural Tanzania," Journal of Public Economics, 85(2): 235-73.

Maskin, Eric, and Jean Tirole. 2004. "The Politician and the Judge: Accountability in Government”, American Economic Review, 94(4): 1034-1054

Mann, Michael. 1986. The Sources of Social Power: A History of Power from the Beginning to $A D$ 1760. Cambridge, UK: Cambridge University Press.

Mansuri, Ghazala and Vijayendra Rao, Forthcoming. "Localizing Development: Does Participation Work?” Policy Research Report, Development Research Group, The World Bank

McGee, R. and J. Gaventa. 2010. Synthesis Report: Review of impact and effectiveness of transparency and accountability initiatives. Transparency and Accountability Initiative, Open Society Foundation, London, UK

Montalvo, José G. and Marta Reynal-Querol. 2010. "Ethnic Polarization and the Duration of Civil Wars." Economics of Governance 11(2).

Mullainathan, S. and A. Shleifer, 2002, Media Bias, (National Bureau of Economic Research, Inc, NBER Working Papers: 9295).

Nguyen, Trang and Gerard Lassibille. 2008. "Improving management in education: Evidence from a randomized experiment in Madagascar," MIT Poverty Action Lab Working Paper, Cambridge, MA

North, Douglass C., John Wallis and Barry Weingast. 2009. Violence and Social Orders New York: Cambridge University Press

Olken, B. A., 2007, Monitoring Corruption: Evidence from a Field Experiment in Indonesia. Journal of Political Economy 115, 200-249. 
Pan, Lei and Luc Christiansen. 2011. "Who is vouching for the input voucher:

Decentralized Targeting and Elite Capture in Tanzania," mimeo, World Bank.

Pandey, Priyanka, Sangeeta Goyal and Venkatesh Sundararaman, 2009. “Community participation in public schools: impact of information campaigns in three Indian states." Education Economics 13(3): 355-375

Paul, Samuel, 2002. Holding the State to Account: Citizen Monitoring in Action. Bangalore, Books for Change

Pierce, Steven. 2006. "Looking Like a State: Colonialism and the Discourse of Corruption in Northern Nigeria." Comparative Studies in Society and History 48(4): 887-914

Polity IV. http://www.systemicpeace.org/polity/polity4.htm Downloaded June 1, 2011

Prat, Andrea. 2005. "The Wrong Kind of Transparency", American Economic Review, 95(3): 862-877

Qian, Nancy and David Yanagizawa-Drott. 2010. "Watchdog or Lapdog? The Effect of U.S. Strategic Objectives on Human Rights News Coverage during the Cold War," NBER Working Paper No. 15738.

Rajan, Raghuram. 2009. "Rent Preservation and the Persistence of Underdevelopment", American Economic Journal: Macroeconomics 1(1): 178-218

Reinikka, R. and J. Svensson, 2004, Local Capture: Evidence from a Central Government Transfer Program in Uganda. Quarterly Journal of Economics $119,679-705$.

Reinikka, R. and J. Svensson, 2005. "Fighting Corruption to Improve Schooling: Evidence from a Newspaper Campaign in Uganda", Journal of the European Economic Association, 2005, vol. 3 (2-3): 259-267

Robinson, James A. and Thierry Verdier. 2002. "The Political Economy of Clientelism" CEPR, Working Paper 3205;

Schaffer, F. 2005. "Clean Elections and the Great Unwashed: Vote Buying and Voter Education in the Philippines," Paper Number 21, School of Social Science, Institute of Advanced Study, Princeton NJ

Stromberg, D. 2004a. "Radio's Impact on Public Spending,"Quarterly Journal of Economics, 119(1): 189-221.

Tendler, J. 1997. Good Government in the Tropics, Johns Hopkins University Press, Baltimore, MD 
Teranavithorn, Supee and Gael Raballand. 2009. Transport Prices and Costs in Africa, World Bank.

Tullock, G. 1959. “Some problems of majority voting," Journal of Political Economy, 67: 571-79.

van de Walle, Nicolas. 2001. African Economies and the Politics of Permanent Crisis, 1979-1999. New York: Cambridge University Press.

Vicente, Pedro C. 2010. "Is Vote-buying Effective? Evidence from a field experiment in West Africa," Working Paper, Trinity College, Dublin

Vicente, Pedro C. and Leonard Wantchekon. 2009 "Clientelism and Vote Buying: Lessons from Field Experiments in African Elections". Oxford Review of Economic Policy

Wantchekon, Leonard. 2009. "Can Informed Public Deliberation Overcome Clientelism? Experimental evidence from Benin," Working Paper, Department of Politics, New York University

Wantchekon, Leonard. 2003. "Clientelism and Voting Behavior: Evidence from a Field Experiment in Benin" World Politics 55: 399-422

World Bank. 2003. World Development Report 2004: Making Services Work for Poor People, Washington DC

World Bank. 2007. Uganda: Public Expenditure Review, Report number 40161-UG, Washington, DC

Yanagizawa-Drott, David. 2010. "Propaganda and Conflict: Theory and Evidence from the Rwandan Genocide," Working Paper, Kennedy School of Government, Harvard University

Young, Daniel J. 2009. "Support you can count on? Ethnicity, partisanship, and retrospective voting in Africa," Afrobarometer Working Paper No. 115. 


\begin{tabular}{|c|c|c|c|c|c|c|}
\hline \multicolumn{7}{|c|}{$\begin{array}{l}\text { Table 1: } \\
\text { Civil Society Activity Across Countries: Afrobarometer Round 4, } 2008\end{array}$} \\
\hline \multirow[t]{2}{*}{ Country } & \multicolumn{6}{|c|}{ Percentage of Respondents Answering "Yes" to: } \\
\hline & $\begin{array}{l}\text { Voted in } \\
\text { last } \\
\text { elections }\end{array}$ & $\begin{array}{l}\text { Active } \\
\text { member of } \\
\text { a group }\end{array}$ & $\begin{array}{l}\text { Often } \\
\text { attended } \\
\text { group } \\
\text { meetings }\end{array}$ & $\begin{array}{c}\text { Often } \\
\text { joined } \\
\text { others } \\
\text { to raise } \\
\text { an issue }\end{array}$ & $\begin{array}{l}\text { Willing to } \\
\text { demonstrate } \\
\text { or protest }\end{array}$ & $\begin{array}{c}\text { Punishment } \\
\text { likely if } \\
\text { people } \\
\text { complain }\end{array}$ \\
\hline \multicolumn{7}{|c|}{ Polity IV Score Between 10 and 6 ("full democracies") } \\
\hline South Africa & 65 & 16 & 29 & 20 & 45 & 46 \\
\hline Botswana & 59 & 17 & 55 & 39 & 52 & 19 \\
\hline Lesotho & 61 & 28 & 67 & 50 & 52 & 74 \\
\hline Ghana & 81 & 35 & 40 & 38 & 30 & 32 \\
\hline Senegal & 79 & 28 & 60 & 55 & 62 & 60 \\
\hline Mali & 77 & 29 & 57 & 55 & 59 & 46 \\
\hline Kenya & 79 & 43 & 44 & 35 & 40 & 37 \\
\hline Benin & 91 & 23 & 53 & 50 & 65 & 25 \\
\hline Zambia & 59 & 24 & 45 & 33 & 45 & 47 \\
\hline Liberia & 78 & 45 & 50 & 42 & 24 & 40 \\
\hline Malawi & 75 & 22 & 60 & 54 & 50 & 27 \\
\hline Avg: & 73.09 & 28.18 & 50.91 & 42.82 & 47.64 & 41.18 \\
\hline \multicolumn{7}{|c|}{ Polity IV Score Between 6 and 2: } \\
\hline Mozambique & 60 & 18 & 49 & 45 & 57 & 47 \\
\hline Nigeria & 60 & 27 & 30 & 26 & 43 & 57 \\
\hline Avg: & 60 & 22.5 & 39.5 & 35.5 & 50 & 52 \\
\hline \multicolumn{7}{|c|}{ Polity IV Score Between 2 and -2: } \\
\hline Zimbabwe & 61 & 16 & 51 & 38 & 42 & 44 \\
\hline Madagascar & 70 & 4 & 75 & 29 & 20 & 61 \\
\hline Burkina & 72 & 18 & 59 & 52 & 63 & 53 \\
\hline Uganda & 70 & 31 & 44 & 33 & 35 & 41 \\
\hline Tanzania & 82 & 35 & 64 & 51 & 65 & 57 \\
\hline Avg: & 71 & 20.80 & 58.6 & 40.6 & 45 & 51.2 \\
\hline
\end{tabular}




\begin{tabular}{|c|c|c|c|c|c|c|c|c|c|}
\hline \multicolumn{10}{|c|}{$\begin{array}{c}\text { Appendix } \\
\text { Literature Review } \\
\text { (Prepared by Avnish Gungadurdoss) }\end{array}$} \\
\hline Paper Title & $\begin{array}{l}\text { Country/ } \\
\text { Region }\end{array}$ & $\begin{array}{l}\text { Leg of } \\
\text { Triangle }\end{array}$ & Mechanism & How & $\begin{array}{l}\text { Role played by } \\
\text { civil society } \\
\text { actors }\end{array}$ & $\begin{array}{l}\text { Nature of } \\
\text { Analysis }\end{array}$ & $\begin{array}{l}\text { Category } \\
\text { of } \\
\text { findings }\end{array}$ & $\begin{array}{l}\text { Measured } \\
\text { Impacts }\end{array}$ & Abstract \\
\hline $\begin{array}{l}\text { Katherine Casey, } \\
\text { Rachel } \\
\text { Glennerster, } \\
\text { Edward Miguel, } \\
\text { Experimental } \\
\text { Evidence on } \\
\text { External Aid and } \\
\text { Community } \\
\text { Institutions in } \\
\text { Sierra Leone, JPAL } \\
\text { working papers }\end{array}$ & $\begin{array}{l}\text { Sierra } \\
\text { Leone }\end{array}$ & $\begin{array}{l}\text { Compact, } \\
\text { Client } \\
\text { Power, } \\
\text { Politics }\end{array}$ & $\begin{array}{l}\text { Solving } \\
\text { collective } \\
\text { action } \\
\text { problems }\end{array}$ & $\begin{array}{l}\text { Provided an } \\
\text { opportunitiy } \\
\text { for collective } \\
\text { enterprise, } \\
\text { founded on } \\
\text { democratic } \\
\text { institutions } \\
\text { meant to } \\
\text { empower the } \\
\text { marginalized. } \\
\text { The hope } \\
\text { then is that } \\
\text { those } \\
\text { artificial } \\
\text { institutions } \\
\text { would spill } \\
\text { over onto } \\
\text { existing } \\
\text { norms. }\end{array}$ & $\begin{array}{l}\text { This was a } \\
\text { government } \\
\text { initiative in line } \\
\text { with the post- } \\
\text { conflict } \\
\text { decentralization } \\
\text { strategy: } \\
\text { Facilitators } \\
\text { introduced } \\
\text { practices aimed } \\
\text { at making local } \\
\text { decision- } \\
\text { making more } \\
\text { democratic. }\end{array}$ & $\mathrm{RCT}$ & $\begin{array}{l}\text { Improved } \\
\text { Service } \\
\text { Delivery }\end{array}$ & $\begin{array}{l}\text { 1) Improved } \\
\text { service delivery } \\
\text { (public goods) } \\
\text { but no } \\
\text { distinction are } \\
\text { made regarding } \\
\text { the channels } \\
\text { (addressing } \\
\text { accountability } \\
\text { or simply } \\
\text { higher input of } \\
\text { resources) } \\
\text { 2) No impact on } \\
\text { village-level } \\
\text { institutions } \\
\text { (inclusiveness } \\
\text { in decision- } \\
\text { making, better } \\
\text { collective } \\
\text { action ability, } \\
\text { etc..) }\end{array}$ & $\begin{array}{l}\text { Abstract: Institutional performance is } \\
\text { thought to be a key determinant of economic } \\
\text { success, however there is little evidence on } \\
\text { how best to reform existing institutions. } \\
\text { Foreign aid donors spend substantial } \\
\text { resources on - community driven } \\
\text { development programs that combine the } \\
\text { provision of public goods with intensive long } \\
\text { term facilitation designed to strengthen local } \\
\text { institutions; make them more democratic and } \\
\text { inclusive of marginalized social groups; and } \\
\text { enhance the capacity of communities to } \\
\text { engage in collective action. This paper } \\
\text { evaluates the effectiveness of one such } \\
\text { program in post-war Sierra Leone using a } \\
\text { randomized methodology. Data collection } \\
\text { combined rich survey instruments with a set } \\
\text { of novel structured community activities } \\
\text { designed to measure how real world } \\
\text { collective action and participation changed } \\
\text { over the four year program (2005-2009). We } \\
\text { find positive impacts on the establishment of } \\
\text { local development committees, local public } \\
\text { goods provision, links between communities } \\
\text { and local government officials, household } \\
\text { economic welfare, and village-level market } \\
\text { activity. However, we do not find any } \\
\text { program impacts on community social } \\
\text { norms, the role of women and youths in local } \\
\text { affairs, more egalitarian decision making or } \\
\text { the capacity for collective action beyond the } \\
\text { immediate project sphere. Overall, these } \\
\text { findings suggest that community driven } \\
\text { development programs and related donor } \\
\text { projects may leave communities materially } \\
\text { better off but may be less effective in } \\
\text { fundamentally transforming local institutions } \\
\text { or power dynamics. }\end{array}$ \\
\hline $\begin{array}{l}\text { Abhijit Banerjee, } \\
\text { Esther Duflo, } \\
\text { "Addressing } \\
\text { Absence" The } \\
\text { Journal of } \\
\text { Economic }\end{array}$ & \multicolumn{8}{|c|}{ THIS PAPER REVIEWS THE NEXT 3 STUDIES DESCRIBED IN GREATER DETAIL BELOW: } & \\
\hline
\end{tabular}




\begin{tabular}{|c|c|c|c|c|c|c|c|c|c|}
\hline $\begin{array}{l}\text { Perspectives, Vol. } \\
\text { 20, No. } 1 \text { (Winter, } \\
\text { 2006), pp. 117-132 }\end{array}$ & & & & & & & & & \\
\hline $\begin{array}{l}\text { Duflo, Esther and } \\
\text { Rema Hanna. } \\
\text { 2005. "Monitoring } \\
\text { Works: Getting } \\
\text { Teachers to Come } \\
\text { to School." Mimeo, } \\
\text { Massachusetts } \\
\text { Institute of } \\
\text { Technology }\end{array}$ & India & Compact & $\begin{array}{l}\text { Financial } \\
\text { sanctions } \\
\text { and benefits }\end{array}$ & $\begin{array}{l}\text { Linking } \\
\text { bonus and } \\
\text { penalties to } \\
\text { attendance } \\
\text { rate, recorded } \\
\text { using tamper- } \\
\text { proof } \\
\text { cameras }\end{array}$ & $\begin{array}{l}\text { NGO (Seva } \\
\text { Mandir) } \\
\text { monitored } \\
\text { teacher } \\
\text { attendance with } \\
\text { the help of } \\
\text { clients - } \\
\text { children in } \\
\text { school in charge } \\
\text { of taking } \\
\text { pictures }\end{array}$ & $\mathrm{RCT}$ & $\begin{array}{l}\text { Improved } \\
\text { Service } \\
\text { Delivery }\end{array}$ & $\begin{array}{l}\text { Increased } \\
\text { teacher } \\
\text { attendance and } \\
\text { children-days }\end{array}$ & $\begin{array}{l}\text { The RCT's treatment was to link teacher's } \\
\text { bonuses and penalties to their attendance } \\
\text { levels. Using cameras with tamper-proof date } \\
\text { and time function to monitor daily } \\
\text { attendance, the experiment decreased } \\
\text { absence rate by half. When in school, } \\
\text { teachers were as likely to teach in both } \\
\text { control and treatment groups. Despite that, } \\
\text { given increases in teacher attendance, the } \\
\text { number of children-days taught in treatment } \\
\text { increased by one third. In addition, given } \\
\text { structure of the pay, the average salary in the } \\
\text { two groups was almost equal. The cost of the } \\
\text { cameras and administration of the program } \\
\text { amounted to } \$ 6 \text { per child per year for an } \\
\text { increase of over } 30 \text { percent in the number of } \\
\text { days the child is taught, }\end{array}$ \\
\hline $\begin{array}{l}\text { Kremer, Michael } \\
\text { and Daniel Chen. } \\
\text { 2001. "An Interim } \\
\text { Report on a } \\
\text { Teacher } \\
\text { Attendance } \\
\text { Incentive Program } \\
\text { in Kenya." Mimeo, } \\
\text { Harvard University }\end{array}$ & Kenya & Compact & $\begin{array}{l}\text { Financial } \\
\text { sanctions } \\
\text { and benefits }\end{array}$ & $\begin{array}{l}\text { Linking } \\
\text { bonus to } \\
\text { attendence } \\
\text { rate - } \\
\text { monitoring } \\
\text { and } \\
\text { distribution } \\
\text { done by } \\
\text { headmaster }\end{array}$ & $\begin{array}{l}\text { NGO (ICS } \\
\text { Africa) funded } \\
\text { and } \\
\text { implemented } \\
\text { the incentive } \\
\text { system }\end{array}$ & $\mathrm{RCT}$ & None & No effect & $\begin{array}{l}\text { This experiment explored the idea of } \\
\text { boosting teacher attendance with a prize (a } \\
\text { bicycle). The allocation of the prize was to } \\
\text { be determined by the headmaster. In all } \\
\text { treatment schools, the headmasters marked } \\
\text { the preschool teachers present a sufficient } \\
\text { number of times for them to receive the prize } \\
\text { (and they therefore all got it). However, } \\
\text { when the research team independently } \\
\text { verified absence through unannounced visits } \\
\text { in both treatment and comparison schools, } \\
\text { they found that the absence rate was actually } \\
\text { at exactly the same high level in treatment } \\
\text { and in comparison schools. Either to avoid } \\
\text { the unpleasantness of a personal } \\
\text { confrontation, or out of compassion for the } \\
\text { preschool teachers, headmasters apparently } \\
\text { cheated to make sure that the preschool } \\
\text { teachers could get the prizes. This outcome } \\
\text { suggests that when human judgment is } \\
\text { involved in a system where rules are often } \\
\text { bent, incentives may easily be perverted, } \\
\text { either as in this case in an equitable direction } \\
\text { or to favor some specific individuals or } \\
\text { groups. }\end{array}$ \\
\hline
\end{tabular}


Glewwe, Paul, Nauman Ilias and Michael Kremer. 2003. "Teacher Incentives."

Mimeo, Harvard University
Linking

bonus to

sanctions objective

and benefits performance

measures
NGO (ICS

Africa) funded

and

implemented

the incentive

system
Improved
Improved

service delivery

as measured by

short-term

outcomes (test

scores) but no

effect on long-

term

educationa

outcomes.
The Kenyan experiment provides incentives to teachers based on the test scores of students in their class. ICS Africa (NGO) provided prizes to teachers in grades 4 to 8 based on the performance of the school as a whole on the district exams in each year. All teachers who taught these grades were eligible for the prize. Prizes were awarded in two categories: "Top-scoring schools" and "Most-improved schools." Schools could not win in more than one category.

Improvements were calculated relative to performance in the base-line year. In each category, three first, second, third and fourth prizes were awarded. Out of the 50 schools participating in the program, 24 received prizes of some type, and teachers in most schools should have felt that they had a chance of winning a prize. Prizes ranged in value from 21 to 43 percent of typical teacher monthly salaries.

The comparison of the 50 treatment and 50 control schools suggested that this program did improve performance in the district exams (by about 0.14 standard deviations), but had no effect on teacher attendance. Instead, the teachers held more test preparation sessions. This, the authors conclude, was rational based on the (limited) evidence on what is most effective in improving test scores over the short horizon. However, these preparation sessions are probably poor substitutes for regular classes. This method of pushing up test scores did little for long-term learning, as evidenced by the fact that once the program ended, students who had been in the program schools did not out-perform those in control schools. The lesson from this experiment seems to be that if we want to boost teacher attendance by providing incentives for teachers, the incentive must be tied directly to attendance. Incentives help teachers get a better sense of what their objectives are and will lead them to focus on the most painless way to achieve this particular objective 


\begin{tabular}{|c|c|c|c|c|c|c|c|c|c|}
\hline $\begin{array}{l}\text { Banerjee, Abhijit, } \\
\text { Angus Deaton and } \\
\text { Esther Duflo. } \\
\text { 2004a. "Health } \\
\text { Care Delivery in } \\
\text { Rural Rajasthan." } \\
\text { Economic and } \\
\text { Political Weekly. } \\
\text { 39:9, pp. 944-49. }\end{array}$ & India & $\begin{array}{l}\text { Client } \\
\text { Power }\end{array}$ & $\begin{array}{l}\text { 1) Improved } \\
\text { information } \\
\text { 2) Financial } \\
\text { sanctions } \\
\text { and benefits }\end{array}$ & $\begin{array}{l}\text { Disseminatin } \\
\mathrm{g} \text { information } \\
\text { on attendance } \\
\text { on weekly } \\
\text { basis }\end{array}$ & $\begin{array}{l}\text { Community } \\
\text { member } \\
\text { individually } \\
\text { monitored } \\
\text { health } \\
\text { employees and } \\
\text { reporting to } \\
\text { other } \\
\text { community } \\
\text { members }\end{array}$ & RCT & None & No effect & $\begin{array}{l}\text { The experiment explores if and how villagers } \\
\text { organize themselves to discipline service } \\
\text { providers upon provision of monitoring } \\
\text { information regarding the attendance rates of } \\
\text { the service providers. A member of the } \\
\text { community was paid to check once a week, } \\
\text { on unannounced days, whether the auxiliary } \\
\text { nurse-midwife assigned to the health sub- } \\
\text { center was present in the center, and if she } \\
\text { was not there, whether she could be found in } \\
\text { the village. A parallel system (a monthly } \\
\text { visit by a member of the survey team, on the } \\
\text { same day) confirmed that this system of local } \\
\text { monitoring was properly implemented: } \\
\text { external monitors and community members } \\
\text { found similar absence rates. However, no } \\
\text { attempt was made to impose an external } \\
\text { reward system for the nurse-midwives based } \\
\text { on the monitoring information. The idea } \\
\text { behind this experiment was to let the } \\
\text { villagers choose how they would use the } \\
\text { monitoring information they were } \\
\text { generating. For example, the villagers could } \\
\text { choose to put explicit pressure on the nurse- } \\
\text { midwife or try to shame her by exposing her } \\
\text { absences. They could even promise her some } \\
\text { explicit rewards. In this case, the collective } \\
\text { action problem in monitoring stood in the } \\
\text { way of effective local control. }\end{array}$ \\
\hline $\begin{array}{l}\text { Martina Björkman, } \\
\text { Jakob Svensson } \\
\text { (2007) "Power to } \\
\text { the People: } \\
\text { Evidence from a } \\
\text { Randomized Field } \\
\text { Experiment of a } \\
\text { Community-Based } \\
\text { Monitoring Project } \\
\text { in Uganda" Policy } \\
\text { Research Working } \\
\text { Paper Series } 4268 \text {, } \\
\text { The World Bank }\end{array}$ & Uganda & $\begin{array}{l}\text { Client } \\
\text { Power }\end{array}$ & $\begin{array}{l}\text { 1) Solving } \\
\text { collective } \\
\text { action } \\
\text { problems } \\
\text { 2) Improved } \\
\text { information }\end{array}$ & $\begin{array}{l}\text { Disseminate } \\
\text { information } \\
\text { on } \\
\text { community's } \\
\text { entitlements, } \\
\text { aggregate } \\
\text { outcomes, } \\
\text { status of } \\
\text { health service } \\
\text { delivery } \\
\text { compared to } \\
\text { other } \\
\text { communities } \\
\text { \& external } \\
\text { support by } \\
\text { local NGO in } \\
\text { addressing } \\
\text { the free-rider } \\
\text { problem of } \\
\text { monitoring } \\
\text { by increasing }\end{array}$ & $\begin{array}{l}\text { Community- } \\
\text { based } \\
\text { organizations } \\
\text { facilitated } \\
\text { initial } \\
\text { dessemination } \\
\text { of report cards } \\
\text { at community } \\
\text { meetings. They } \\
\text { also guided } \\
\text { community } \\
\text { members in } \\
\text { designing a } \\
\text { monitoring plan } \\
\text { and revising it } \\
\text { midway } \\
\text { through the } \\
\text { program }\end{array}$ & $\mathrm{RCT}$ & $\begin{array}{l}\text { Improved } \\
\text { Service } \\
\text { Delivery }\end{array}$ & $\begin{array}{l}\text { The quantity of } \\
\text { services } \\
\text { delivered } \\
\text { increases }\end{array}$ & $\begin{array}{l}\text { Strengthening the relationship of } \\
\text { accountability between health service } \\
\text { providers and citizens is by many people } \\
\text { viewed as critical for improving access to } \\
\text { and quality of health care. How this is to be } \\
\text { achieved, and whether it works, however, } \\
\text { remain open questions. This paper presents a } \\
\text { randomized field experiment on increasing } \\
\text { community-based monitoring. As } \\
\text { communities began to more extensively } \\
\text { monitor the provider, both the quality and } \\
\text { quantity of health service provision } \\
\text { improved. One year into the program, we } \\
\text { find large increases in utilization, significant } \\
\text { weight-for-age z-score gains of infants, and } \\
\text { markedly lower deaths among children. The } \\
\text { findings on state's behavior suggest that the } \\
\text { improvements in quality and quantity of } \\
\text { health service delivery resulted from an } \\
\text { increased effort by the state to serve the } \\
\text { community. Overall, the results suggest that }\end{array}$ \\
\hline
\end{tabular}




\begin{tabular}{|c|c|c|c|c|c|c|c|c|c|}
\hline & & & & $\begin{array}{l}\text { organizationa } \\
1 \text { capacity and } \\
\text { encouraging } \\
\text { communities } \\
\text { to develop } \\
\text { their own } \\
\text { monitoring } \\
\text { strategy that } \\
\text { they could } \\
\text { manage and } \\
\text { sustain }\end{array}$ & & & & & $\begin{array}{l}\text { community monitoring can play an important } \\
\text { role in improving service delivery when } \\
\text { traditional top-down supervision is } \\
\text { ineffective. }\end{array}$ \\
\hline $\begin{array}{l}\text { Martina Björkman } \\
\text { \& Jakob Svensson } \\
\text { (2010) "When Is } \\
\text { Community-Based } \\
\text { Monitoring } \\
\text { Effective? Evidence } \\
\text { from a Randomized } \\
\text { Experiment in } \\
\text { Primary Health in } \\
\text { Uganda," Journal } \\
\text { of the European } \\
\text { Economic } \\
\text { Association, MIT } \\
\text { Press, vol. 8(2-3), } \\
\text { pages 571-581, 04- } \\
\text { 05. } \\
\text { Follow up on } \\
\text { above study }\end{array}$ & Uganda & $\begin{array}{l}\text { Client } \\
\text { Power }\end{array}$ & $\begin{array}{l}\text { 1) Solving } \\
\text { collection } \\
\text { action } \\
\text { problem }\end{array}$ & $\begin{array}{l}\text { same as } \\
\text { above }\end{array}$ & same as above & RCT & $\begin{array}{l}\text { Improved } \\
\text { Service } \\
\text { Delivery }\end{array}$ & $\begin{array}{l}\text { The } \\
\text { improvement in } \\
\text { services is } \\
\text { largest for the } \\
\text { most } \\
\text { homogenous } \\
\text { communities, } \\
\text { signifying that } \\
\text { there is a } \\
\text { greater ability } \\
\text { to coordinate } \\
\text { collective } \\
\text { action within } \\
\text { ethnic groups as } \\
\text { compared to } \\
\text { across ethnic } \\
\text { groups. }\end{array}$ & $\begin{array}{l}\text { This is a follow-up examination of the above } \\
\text { experiment (Bjorkman, Svensson 2009) } \\
\text { focusing on the effect of communities' social } \\
\text { heterogeneity on their ability to address the } \\
\text { collective action problem. Evidence reveals } \\
\text { substantial heterogeneous treatment effects } \\
\text { within the treated group. Using data from the } \\
\text { randomized experiment in primary health in } \\
\text { Uganda (described above), the authors test } \\
\text { whether social heterogeneity can explain } \\
\text { why some treated communities managed to } \\
\text { push for better health service delivery while } \\
\text { others did not. The results suggest that } \\
\text { income inequality, and particularly ethnic } \\
\text { fractionalization, adversely impact collective } \\
\text { action for improved service provision. }\end{array}$ \\
\hline $\begin{array}{l}\text { Mary Kay Gugerty } \\
\text { and Michael } \\
\text { Kremer, "Outside } \\
\text { Funding and the } \\
\text { Dynamics of } \\
\text { Participation in } \\
\text { Community } \\
\text { Associations", } \\
\text { American Journal } \\
\text { of Political } \\
\text { Science, Vol. 52, } \\
\text { No. } 3 \text { (Jul., 2008), } \\
\text { pp. } 585-602\end{array}$ & Kenya & $\begin{array}{l}\text { Group } \\
\text { Formation } \\
\text { Client } \\
\text { power }\end{array}$ & $\begin{array}{l}\text { 1) Solving } \\
\text { collection } \\
\text { action } \\
\text { problem }\end{array}$ & $\begin{array}{l}\text { External } \\
\text { funding for } \\
\text { local } \\
\text { women's } \\
\text { associations }\end{array}$ & $\begin{array}{l}\text { International } \\
\text { NGO } \\
\text { (International } \\
\text { Child Support) } \\
\text { provided } \\
\text { assistance in the } \\
\text { form of } \\
\text { agricultural } \\
\text { inputs, } \\
\text { organizational } \\
\text { and group } \\
\text { management } \\
\text { training and } \\
\text { agricultural } \\
\text { training in the } \\
\text { hope of } \\
\text { strengthening } \\
\text { the group } \\
\text { membership }\end{array}$ & RCT & $\begin{array}{l}\text { Shifts in } \\
\text { inequalitie } \\
\text { s of } \\
\text { access/infl } \\
\text { uence }\end{array}$ & $\begin{array}{l}\text { 1) Outside } \\
\text { funding did not } \\
\text { expand } \\
\text { organizational } \\
\text { strength, } \\
\text { 2) } \\
\text { Substantial evid } \\
\text { ence that } \\
\text { funding } \\
\text { changed group } \\
\text { membership } \\
\text { and leadership, } \\
\text { weakening the } \\
\text { role of the } \\
\text { disadvantaged. }\end{array}$ & $\begin{array}{l}\text { The poor and disadvantaged are widely seen } \\
\text { as having weak organizations and low rates } \\
\text { of participation in community associations, } \\
\text { impeding their political representation and } \\
\text { economic advancement. Many policy } \\
\text { initiatives aim to build civic participation } \\
\text { among the disadvantaged by funding local } \\
\text { community associations. Taking advantage } \\
\text { of random assignment in a program } \\
\text { supporting women's community associations } \\
\text { in Kenya, we find little evidence that outside } \\
\text { funding expanded organizational strength, } \\
\text { but substantial evidence that funding } \\
\text { changed group membership and leadership, } \\
\text { weakening the role of the disadvantaged. The } \\
\text { program led younger, more educated, and } \\
\text { better-off women to enter the groups. New } \\
\text { entrants, men, and more educated women } \\
\text { assumed leadership positions. The departure } \\
\text { of older women, the most socially } \\
\text { marginalized demographic group, increased }\end{array}$ \\
\hline
\end{tabular}




\begin{tabular}{|c|c|c|c|c|c|c|c|c|c|}
\hline & & & & & & & & & $\begin{array}{l}\text { substantially. The results are generalized } \\
\text { through a formal model showing how } \\
\text { democratic decision making by existing } \\
\text { members of community associations can } \\
\text { generate long-run outcomes in which the } \\
\text { poor and disadvantaged either do not belong } \\
\text { to any associations or belong to weak } \\
\text { organizations. }\end{array}$ \\
\hline $\begin{array}{l}\text { NGO REPORT } \\
\text { (2004) "Rural } \\
\text { Initiatives and } \\
\text { Relief Agency } \\
\text { (RIRA) - Report } \\
\text { for a Pilot Public } \\
\text { Expenditure } \\
\text { Tracking in } 10 \\
\text { Villages of Magu } \\
\text { District". } \\
\text { Partnership for } \\
\text { Transparency. }\end{array}$ & Tanzania & $\begin{array}{l}\text { Client } \\
\text { Power }\end{array}$ & $\begin{array}{l}\text { 1) Improved } \\
\text { information }\end{array}$ & $\begin{array}{l}\text { External } \\
\text { support by } \\
\text { NGO }\end{array}$ & $\begin{array}{l}\text { Local NGO } \\
\text { RIRA } \\
\text { undertook } \\
\text { public } \\
\text { expenditure } \\
\text { tracking }\end{array}$ & $\begin{array}{l}\text { Qualitativ } \\
\text { e }\end{array}$ & $\begin{array}{l}\text { Improved } \\
\text { Service } \\
\text { Delivery }\end{array}$ & $\begin{array}{l}\text { 1) The project } \\
\text { was effective in } \\
\text { those villages in } \\
\text { ensuring that } \\
\text { commitments to } \\
\text { deliver funds } \\
\text { for health and } \\
\text { education were } \\
\text { met. }\end{array}$ & $\begin{array}{l}\text { In Tanzania, corruption posed a threat to } \\
\text { successful implementation of poverty } \\
\text { reduction strategies. To tackle this problem, } \\
\text { the government undertook public } \\
\text { expenditure reviews (PER) in priority areas } \\
\text { such as education and health. Given the } \\
\text { highly participatory environment under } \\
\text { which the country had undertaken its strategy } \\
\text { and reform process, in } 2004 \text { a local NGO- } \\
\text { the Rural Initiatives and Relief Agency } \\
\text { (RIRA) -undertook a pilot funded by the } \\
\text { Partnership for Transparency Fund to track } \\
\text { public expenditures. Without public access to } \\
\text { information on local government budgets and } \\
\text { spending, officials cannot be held } \\
\text { accountable. The NGO saw a need in } \\
\text { Tanzania- where local government } \\
\text { authorities must disseminate information on } \\
\text { revenues and expenditures-to develop a } \\
\text { model for effective monitoring and } \\
\text { evaluation in villages. There was particular } \\
\text { emphasis on education, which represents the } \\
\text { largest disbursement to villages. } \\
\text { - According to a RIRA survey, only 10 } \\
\text { percent of villagers had seen information on } \\
\text { education or health spending, required by } \\
\text { law. The project found that communities } \\
\text { were not involved in decision-making, } \\
\text { received little information, and cannot easily } \\
\text { lodge grievances. } \\
\text { - In 2004, the pilot-program assisted } \\
\text { communities in track government } \\
\text { disbursements for health and education } \\
\text { development for ten villages in the Magu } \\
\text { district. } \\
\text { - A replicable model for public expenditure } \\
\text { tracking was built. } \\
\text { - The project mobilized community } \\
\text { participation in public expenditure tracking. }\end{array}$ \\
\hline
\end{tabular}


Trang Nguyen, Gerard Lassibille, Improving Management in Education:

Evidence from a Randomized

Experiment in Madagascar, MIT Poverty Action Lab Working Paper, June 2008
1) Improved information 2) Leveraging social sanctions through regular meetings between school

teachers and parents
Group of support by (beneficiaries) Government, attended in terms of meetings where training for report cards of district and teacher sub-district performance administrator were

s and teachers distributed, as well as to giving structure $\quad$ credibility to parentsteachers meetings
Service

Delivery

the social

sanction

mechanism at play.
1) Top-down monitoring by district and subdistrict administrators had no significant impacts

2) Beneficiary monitoring improved test scores by 0.1 standard

deviations after 2 years and teacher's

behavior improved in lesson planning and giving evaluations. Tasks that did were not specifically measured, such as teacher attendance or communication with parents, did not improve.

\section{Public}

Expenditure Tracking surveys, when ric - IV estimation and difference -indifference
This paper evaluates several interventions in Madagascar that sought to promote top-down and local monitoring of the school to improve education quality. Randomly selected school districts and subdistricts received operational tools to facilitate the administrators' supervision tasks. Randomly selected schools in these treated districts were reinforced with teacher tools and parent-teacher meetings centered around a school report card. The other schools in treated districts did not receive any direct intervention; it was up to the administrators to distribute the report cards and tools, and implement effective monitoring in those places. We find little impact of targeting district and subdistrict administrators on their behavior and on the performance of the schools under their jurisdiction. Meanwhile, the intervention implemented at the school level led to an improvement in various observable performance measures. Teachers prepared lesson plans and evaluated their students more frequently. Teacher attendance and communication with parents did not improve, consistent with predictions of the multitasking principal-agent problem. On balance, the effect of the school intervention on student attendance was positive: 4.3 percentage point increase from $87 \%$ mean attendance. Test scores also improved by 0.1 standard deviations after two years, particularly in math and Malagasy. These results suggest that improving management via mediated control in the hands of government bureaucrats does not do much in this context, while beneficiary monitoring leads to an improvement in teaching activities and student achievement.

This paper demonstrates that public service capture of government funds should increase as information regarding funding becomes more available to the public. The author studied central government funding received by public schools in Uganda after a 1996 newspaper campaign to provide grant information to schools and parents. Average school capture of central government grants increased from $20 \%$ before the campaign to $80 \%$ in 2001 . As teachers demonstrated more 


\begin{tabular}{|c|c|c|c|c|c|}
\hline $\begin{array}{l}\text { Association 3 (2- } \\
\text { 3): } 259-267 .\end{array}$ & & $\begin{array}{l}\text { parents and } \\
\text { schools }\end{array}$ & & $\begin{array}{l}\text { leakages in } \\
\text { delivery of } \\
\text { service sector } \\
\text { budgets locally }\end{array}$ & $\begin{array}{l}\text { knowledge of grant capture in a survey } \\
\text { conducted during the study and as the } \\
\text { distance to a newspaper stand from the } \\
\text { school decreased, the percent of grant money } \\
\text { captured by the school increased. }\end{array}$ \\
\hline $\begin{array}{l}\text { Hubbard, P. (2007) } \\
\text { 'Putting the Power } \\
\text { of Transparency in } \\
\text { Context: } \\
\text { Information's Role } \\
\text { in Reducing } \\
\text { Corruption in } \\
\text { Uganda's } \\
\text { Education Sector.' } \\
\text { Working Paper } \\
\text { Number 136. } \\
\text { Washington, DC: } \\
\text { Center for Global } \\
\text { Development. } \\
\text { Available at } \\
\text { http://www.cgdev.o } \\
\text { rg/content/publicati } \\
\text { ons/detail/15050/ }\end{array}$ & Uganda & $\begin{array}{l}\text { THIS PAPER OFFERS A DIRECT CF } \\
\text { SVENSSON PAPER DESCRIBED AB } \\
\text { there were concurring changes in Polit }\end{array}$ & $\begin{array}{l}\text { TICISM OF THE RENIKKA AND } \\
\text { VE --> More specifically it claims that } \\
\text { and Compact as well. }\end{array}$ & $\begin{array}{l}\text { "It is a mistake } \\
\text { to attribute the } \\
\text { entire reduction } \\
\text { in corruption to } \\
\text { a single } \\
\text { publication } \\
\text { policy. } \\
\text { Reinikka and } \\
\text { Svennson's } \\
\text { research } \\
\text { focuses on a } \\
\text { small but } \\
\text { significant } \\
\text { element - } \\
\text { information } \\
\text { provided } \\
\text { through } \\
\text { newspapers to } \\
\text { local schools. } \\
\text { But their } \\
\text { research is best } \\
\text { understood in } \\
\text { terms of } \\
\text { concurrent } \\
\text { reforms in } \\
\text { Uganda's } \\
\text { education and } \\
\text { fiscal systems. } \\
\text { This paper } \\
\text { examines a } \\
\text { number of other } \\
\text { policies and } \\
\text { reforms that } \\
\text { help explain the } \\
\text { reported decline } \\
\text { in corruption to } \\
\text { Ugandan } \\
\text { education in the } \\
\text { 1990s." }\end{array}$ & $\begin{array}{l}\text { One of the popular stories told (and taught) } \\
\text { in development circles is how corruption was } \\
\text { slashed in Uganda simply by publishing the } \\
\text { amount of monthly grants to schools. This } \\
\text { paper takes a deeper look at the facts behind } \\
\text { the Uganda story and finds that while } \\
\text { information did indeed play a critical role, } \\
\text { the story is much more complicated than we } \\
\text { have been led to believe. A dramatic drop did } \\
\text { occur in the percentage of funds being } \\
\text { diverted from Uganda's capitation grant. But } \\
\text { to attribute this leakage solely to the monthly } \\
\text { release of grant data by the government risks } \\
\text { ignoring the major funding in which this } \\
\text { transparency campaign was imbedded }\end{array}$ \\
\hline
\end{tabular}


Tsai, L. L,

"Solidary groups, informal

accountability, and local public goods provision in rural china", 2007, American Political Science Review 101, (02): 355-72.

WORLD BANK REPORT: "Paying Primary Health Care Centers for Performance in Rwanda", Policy Research Working Paper 5190.
Client

Power

China and/or

Local

Politics

Social

official with

Benefits

'moral

standing' for

above

average

performance

and hence

incentivize

public good

provision
This is a

model of

informal

award public

Sanctions / valuable government

accountability

whereby

citizens

illagers create

and leverage

encompassing

and powerful

social networks

(such as

religious

groups) to

sanction/

incentivize

local officials

and elected

Linking

payment to

performance,

measured by

quantity and

quality

indicators representatives

In the absence of strong

institutions and

in the presence

of weak formal

accountability

systems,

embedding

Improved public officials

Service or elected

Delivery representatives

in

encompassing

social groups

(solidary

groups) lead to

higher levels of

public good

provision.

\section{Pay for}

performance

incentivizes

providers to

increase service

delivery (where

possible) and

also increase

quality of

services. In

addition, when

particular

services (such

Difference Improved service

systems -in-

$\mathrm{n} / \mathrm{a}$

difference
Why would government officials in

authoritarian and transitional systems where formal democratic and bureaucratic

institutions of accountability are often weak ever provide more than the minimum level of public goods needed to maintain social stability? Findings from a unique

combination of in-depth case study research and an original survey of 316

villages in rural China indicate that even

when formal accountability is weak., local

officials can be subject to unofficial rules and norms that establish and enforce their public obligations. These informal institutions of accountability can be provided by

encompassing and embedding solidary groups. Villages where these types of groups exist are more likely to have better local governmental public goods provision than villages without these solidary groups, all other things being equal

Paying for performance (P4P) provides financial incentives for providers to increase the use and quality of care. P4P can affect health care by providing incentives for providers to put more effort into specific activities, and by increasing the amount of resources available to finance the delivery of services. This paper evaluates the impact of P4P on the use and quality of prenatal, institutional delivery, and child preventive care using data produced from a prospective quasi-experimental evaluation nested into the national rollout of P4P in Rwanda. Treatment facilities were enrolled in the P4P scheme in 2006 and comparison facilities were enrolled two years later. The incentive effect is isolated from the resource effect by increasing comparison facilities' input-based budgets by the average $\mathrm{P} 4 \mathrm{P}$ payments to the treatment facilities. The data were collected from 166 facilities and a random sample of 2158 households. P4P had a large and significant positive impact on institutional deliveries and preventive care visits by young children, and improved quality of prenatal care. The authors find no effect on the number of prenatal care visits or on immunization rates. $\mathrm{P} 4 \mathrm{P}$ had the greatest effect on those services that had the highest 


\begin{tabular}{|c|c|c|c|c|c|c|c|c|c|}
\hline & & & & & & & & $\begin{array}{l}\text { to improve } \\
\text { specific } \\
\text { services. }\end{array}$ & $\begin{array}{l}\text { payment rates and needed the lowest } \\
\text { provider effort. P4P financial performance } \\
\text { incentives can improve both the use of and } \\
\text { the quality of health services. Because the } \\
\text { analysis isolates the incentive effect from the } \\
\text { resource effect in P4P, the results indicate } \\
\text { that an equal amount of financial resources } \\
\text { without the incentives would not have } \\
\text { achieved the same gain in outcomes. }\end{array}$ \\
\hline $\begin{array}{l}\text { Barret Gregory } \\
\text { and Gaventa John, } \\
\text { "So what difference } \\
\text { does it make? } \\
\text { Mapping the } \\
\text { outcomes of Citizen } \\
\text { Engagement", IDS } \\
\text { Working Paper } \\
\text { Volume } 2010 \\
\text { Number } 347\end{array}$ & Various & Various & $\begin{array}{l}\text { Various } \\
\text { types of } \\
\text { citizen } \\
\text { engagement }\end{array}$ & $\mathrm{n} / \mathrm{a}$ & $\mathrm{n} / \mathrm{a}$ & $\begin{array}{l}\text { Qualitativ } \\
\text { e - } \\
\text { Synthesis } \\
\text { of } 100 \\
\text { studies }\end{array}$ & $\mathrm{n} / \mathrm{a}$ & $\begin{array}{l}\text { Maps positive } \\
\text { and negative } \\
\text { outcomes of } \\
\text { citizenship } \\
\text { engagement } \\
\text { initiatives into } 4 \\
\text { different } \\
\text { categories and } \\
\text { offers an insight } \\
\text { on future } \\
\text { approach to } \\
\text { citizen } \\
\text { engagement - } \\
\text { Very good } \\
\text { summary of } \\
\text { qualitative } \\
\text { literature }\end{array}$ & $\begin{array}{l}\text { In this paper, we report on a meta-case study } \\
\text { analysis of a ten-year research programme on } \\
\text { citizenship, participation and accountability, } \\
\text { which analysed a nonrandomized sample of } \\
100 \text { research studies of four types of citizen } \\
\text { engagement in } 20 \text { countries. By mapping the } \\
\text { observable effects of citizen participation } \\
\text { through a close reading of these studies, we } \\
\text { created a typology of four democratic and } \\
\text { developmental outcomes, including (a) the } \\
\text { construction of citizenship, (b) the } \\
\text { strengthening of practices of participation, } \\
\text { (c) the strengthening of responsive and } \\
\text { accountable states, and (d) the development } \\
\text { of inclusive and cohesive societies. We find } \\
\text { that citizen participation produces positive } \\
\text { effects across these outcome types, though in } \\
\text { each category there are also examples of } \\
\text { negative outcomes of citizen participation. } \\
\text { We also find that these outcomes vary } \\
\text { according to the type of citizen engagement } \\
\text { and to political context. These findings have } \\
\text { important implications for the design of and } \\
\text { support for participatory programmes meant } \\
\text { to improve state responsiveness and } \\
\text { effectiveness. }\end{array}$ \\
\hline $\begin{array}{l}\text { Mcgee, Rosemary, } \\
\text { Gaventa John } \\
\text { (2010) "Review of } \\
\text { Impact and } \\
\text { Effectiveness of } \\
\text { Transparency and } \\
\text { Accountability } \\
\text { Initiatives: } \\
\text { Synthesis Report", } \\
\text { Institute of } \\
\text { Development } \\
\text { Studies }\end{array}$ & \multicolumn{8}{|c|}{ ALL STUDIES LISTED BELOW ARE DRAWN FROM THE MCGEE, GAVENTA Synthesis Report } & \\
\hline
\end{tabular}




\begin{tabular}{|c|c|c|c|c|c|c|c|c|c|}
\hline $\begin{array}{l}\text { Ravindra, A. } \\
\text { (2004) 'An } \\
\text { Assessment of the } \\
\text { Impact of } \\
\text { Bangalore Citizen } \\
\text { Report Cards on } \\
\text { the Performance of } \\
\text { Public Agencies.' } \\
\text { Evaluation } \\
\text { Capacity } \\
\text { Development } \\
\text { Working Paper } \\
\text { no.12, Operations } \\
\text { Evaluation } \\
\text { Department. } \\
\text { Washington, DC: } \\
\text { World Bank. } \\
\end{array}$ & India & $\begin{array}{l}\text { Client } \\
\text { Power }\end{array}$ & $\begin{array}{l}\text { 1) Improved } \\
\text { information }\end{array}$ & $\begin{array}{l}\text { User } \\
\text { feedback in } \\
\text { Report cards } \\
\text { can be used } \\
\text { to hold public } \\
\text { officials } \\
\text { accountable }\end{array}$ & $\begin{array}{l}\text { Citizens report } \\
\text { grievances and } \\
\text { civil societies } \\
\text { and NGOs } \\
\text { increase their } \\
\text { level of } \\
\text { activism using } \\
\text { grievances to } \\
\text { hold public } \\
\text { officials and } \\
\text { local } \\
\text { government } \\
\text { accountable }\end{array}$ & $\begin{array}{l}\text { Qualitativ } \\
\mathrm{e}\end{array}$ & $\begin{array}{l}\text { Improved } \\
\text { Service } \\
\text { Delivery }\end{array}$ & $\begin{array}{l}\text { Improved } \\
\text { quality of } \\
\text { services } \\
\text { through } \\
\text { increased civic } \\
\text { activism, } \\
\text { increased public } \\
\text { awareness and } \\
\text { increased client } \\
\text { orientation on } \\
\text { the part of } \\
\text { Public Service } \\
\text { Agencies }\end{array}$ & $\begin{array}{l}\text { This review finds that citizen report cards } \\
\text { have been an important vehicle for civil } \\
\text { society action in Bangalore, and that they } \\
\text { have had a significant impact on the quality } \\
\text { of public services. The review identifies } \\
\text { success factors and considers the replicability } \\
\text { of the report card approach. } 2 \text { citizen Report } \\
\text { Cards, in } 1994 \text { and } 1999 \text {, collected citizen's } \\
\text { feedback on the performance of } 8 \text { major } \\
\text { Public Service Agencies in Bangalore. The } \\
\text { study conducts targeted interviews with } \\
\text { NGOs and to assess the role of and extent to } \\
\text { which report cards align public officials' } \\
\text { performance with public needs. }\end{array}$ \\
\hline $\begin{array}{l}\text { Caseley, J. (2003) } \\
\text { 'Blocked Drains } \\
\text { and Open Minds: } \\
\text { Multiple } \\
\text { Accountability } \\
\text { Relationships and } \\
\text { Improved Service } \\
\text { Delivery } \\
\text { Performance in an } \\
\text { Indian City.' IDS } \\
\text { Working Paper } \\
\text { 211. Brighton, UK: } \\
\text { Institute of } \\
\text { Development } \\
\text { Studies. }\end{array}$ & India & $\begin{array}{l}\text { Client } \\
\text { Power and } \\
\text { Compact }\end{array}$ & $\begin{array}{l}\text { 1) Improved } \\
\text { information } \\
\text { 2) Providing } \\
\text { a compact } \\
\text { with greater } \\
\text { independenc } \\
e \text { from } \\
\text { politicians } \\
\text { and better } \\
\text { performance } \\
\text { measuremen } \\
t\end{array}$ & $\begin{array}{l}\text { 1) Senior } \\
\text { Managers and } \\
\text { front-line } \\
\text { providers } \\
\text { organize } \\
\text { meetings with } \\
\text { citizens to } \\
\text { identify needs } \\
\text { 2) Citizens } \\
\text { also lodge } \\
\text { complaints } \\
\text { through } \\
\text { formal } \\
\text { system to } \\
\text { increase } \\
\text { information } \\
\text { flow } \\
\text { 3) The extent } \\
\text { to which } \\
\text { complaints } \\
\text { are addressed } \\
\text { is used as a } \\
\text { measurement } \\
\text { of } \\
\text { performance }\end{array}$ & $\mathrm{n} / \mathrm{a}$ & $\begin{array}{l}\text { Case- } \\
\text { study }\end{array}$ & $\begin{array}{l}\text { Improved } \\
\text { Service } \\
\text { Delivery }\end{array}$ & $\begin{array}{l}\text { Complaint } \\
\text { mechanisms } \\
\text { can contribute } \\
\text { to reduction of } \\
\text { corruption, by } \\
\text { linking citizens } \\
\text { directly to } \\
\text { managers who } \\
\text { can then hold } \\
\text { managers to } \\
\text { account }\end{array}$ & $\begin{array}{l}\text { How can public sector service providers } \\
\text { deliver improved services to citizens within } \\
\text { environments where inefficient and often } \\
\text { corrupt service delivery is the norm? The } \\
\text { following paper provides some answers to } \\
\text { this question through examining the impact } \\
\text { of a series of customer-focused service } \\
\text { delivery reforms undertaken at the } \\
\text { Hyderabad Metropolitan Water Supply and } \\
\text { Sewerage Board (Metro Water) in } \\
\text { Hyderabad City, Andhra Pradesh state, } \\
\text { Southern India at the end of the 1990s. The } \\
\text { Metro Water case is interesting, as it shows } \\
\text { how a semi-autonomous service provider can } \\
\text { undertake organisational change and realise } \\
\text { sustained improvements in service delivery } \\
\text { performance. If this process is deepened over } \\
\text { time there is a greater opportunity to attract, } \\
\text { and provide security for, larger state or } \\
\text { private sector investments that can impact } \\
\text { water supply and sewerage service delivery } \\
\text { over the long-term. This is the scenario that } \\
\text { emerges in the following case. A key finding } \\
\text { in this research is that multiple accountability } \\
\text { relationships, operating between external } \\
\text { actors and Metro Water staff, have } \\
\text { collectively contributed to sustained } \\
\text { organisational change and improved service } \\
\text { delivery performance. The most critical of } \\
\text { these relationships are those that triangulate } \\
\text { between citizens, senior managers, and } \\
\text { ifront-lineî workers. In the Metro Water case } \\
\text { active citizen engagement through formal }\end{array}$ \\
\hline
\end{tabular}




\begin{tabular}{|c|c|c|c|c|c|c|c|c|c|}
\hline & & & & & & & & & $\begin{array}{l}\text { accountability mechanisms has been the key } \\
\text { to the organisationís overall success in } \\
\text { delivering improved services to citizens } \\
\text { (both middle class and urban poor) } \\
\text { throughout Hyderabad City. }\end{array}$ \\
\hline $\begin{array}{l}\text { Banerjee, A., } \\
\text { Duflo, E., } \\
\text { Glennerster, R., } \\
\text { Banerji, R. and } \\
\text { Khemani, S. (2010) } \\
\text { 'Pitfalls of } \\
\text { Participatory } \\
\text { Programs: } \\
\text { Evidence from a } \\
\text { Randomized } \\
\text { Evaluation of } \\
\text { Education in } \\
\text { India.' American } \\
\text { Economic Journal: } \\
\text { Economic Policy } \\
\text { 2(1): 1-30. }\end{array}$ & India & $\begin{array}{l}\text { Client } \\
\text { Power }\end{array}$ & $\begin{array}{l}\text { 1) Improved } \\
\text { information }\end{array}$ & $\begin{array}{l}\text { Provision of } \\
\text { information, } \\
\text { training of } \\
\text { community } \\
\text { members and } \\
\text { supplementin } \\
\text { g public } \\
\text { education } \\
\text { system with a } \\
\text { parallel } \\
\text { remedial one } \\
\text { motored by } \\
\text { volunteers. }\end{array}$ & $\begin{array}{l}\text { External } \\
\text { support in } \\
\text { experimental } \\
\text { setting }\end{array}$ & $\mathrm{RCT}$ & None & $\begin{array}{l}\text { Information } \\
\text { provision has } \\
\text { been found to } \\
\text { have little } \\
\text { impact by itself } \\
\text { on the level of } \\
\text { engagement by } \\
\text { citizens in } \\
\text { engaging for } \\
\text { accountability } \\
\text { with school } \\
\text { systems in one } \\
\text { study. There is } \\
\text { evidence that } \\
\text { citizens are } \\
\text { constrained and } \\
\text { cannot } \\
\text { participate in } \\
\text { improving the } \\
\text { education } \\
\text { system. This } \\
\text { highlights the } \\
\text { regressive } \\
\text { nature of } \\
\text { participatory } \\
\text { approaches and } \\
\text { also may reflect } \\
\text { the free rider } \\
\text { problem }\end{array}$ & $\begin{array}{l}\text { Participation of beneficiaries in the } \\
\text { monitoring of public services is increasingly } \\
\text { seen as a key to improving their efficiency. } \\
\text { In India, the current government flagship } \\
\text { program on universal primary education } \\
\text { organizes both locally elected leaders and } \\
\text { parents of children enrolled in public schools } \\
\text { into committees and gives these groups } \\
\text { powers over resource allocation, and } \\
\text { monitoring and management of school } \\
\text { performance. However, in a baseline survey } \\
\text { we found that people were not aware of the } \\
\text { existence of these committees and their } \\
\text { potential for improving education. This paper } \\
\text { evaluates three different interventions to } \\
\text { encourage beneficiaries' participation } \\
\text { through these committees: providing } \\
\text { information, training community members in } \\
\text { a new testing tool, and training and } \\
\text { organizing volunteers to hold remedial } \\
\text { reading camps for illiterate children. We find } \\
\text { that these interventions had no impact on } \\
\text { community involvement in public schools, } \\
\text { and no impact on teacher effort or learning } \\
\text { outcomes in those schools. However, we do } \\
\text { find that the intervention that trained } \\
\text { volunteers to teach children to read had a } \\
\text { large impact on activity outside public } \\
\text { schools-local youths volunteered to be } \\
\text { trained to teach, and children who attended } \\
\text { these camps substantially improved their } \\
\text { reading skills. These results suggest that } \\
\text { citizens face substantial constraints in } \\
\text { participating to improve the public education } \\
\text { system, even when they care about education } \\
\text { and are willing to do something to improve } \\
\text { it. }\end{array}$ \\
\hline
\end{tabular}


Pandey, P., Goyal, S. and

Sundararaman, $V$. (2009) 'Community

Participation in Public Schools:

Impact of

Information

Campaigns in

Three Indian

States', Education

Economics 17(3): 287-89.
Information

was given to

increase the

awareness of

parents and

community

members on

important

processes that

influence the

quality of

Client

Power

1) Improved schools. Thus information parents were

empowered

to engage

with the

school system

(with

teachers,

committees,

funding

process, etc..)

and hold it

accountable.
Citizens act

upon

information to

pressurize

school system
When

information

provision is tied

to a

community-

based

information

campaign,

positive impacts

were found on

citizen

engagement,

teacher

engagement and

scholastic

outcomes in

UP, MP and

Karnataka
This study evaluates the impact of a

community-based information campaign on school performance from a cluster

randomized control trial in 610 villages. The campaign consisted of eight or nine public meetings in each of 340 treatment villages across three Indian states to disseminate

information to the community about its statemandated roles and responsibilities in school management. No intervention took place in control villages. At baseline there are no significant differences in school outcomes.

This paper reports on the first follow up survey that took place two to four months after the intervention. We find that providing information through a structured campaign to communities had a positive impact in all

three states. However, there are differences across states in where the impact occurs. The most notable impacts occurred on teacher effort, while impacts on learning were more modest. Some improvements also occurred

in the delivery of benefits entitled to students (stipend, uniform and mid-day meal) and in process variables such as community participation in each of the three states. Future research needs to examine whether there is a systematic increase in learning when the impact is measured over a longer time period and whether a campaign sustained over longer duration generates greater impact on school outcomes. 
Goldfrank, $B$. (2006) 'Lessons from Latin

American

Experience in

Participatory

Budgeting.' Paper

Presented at the

Latin American

Studies Association

Meeting, San Juan,

Puerto Rico,

March.

Available at

http://www.internat

ionalbudget.org/the mes/PB/LatinAmer ica.pdf
Participatory

budgeting

initiatives can

contribute to

multiple

outcomes,

including

improved

public services,

re-direction of

Multiple,

Politics, clients in

decision-

making on

budgets
Cizens

participate in

ecision-

municipalities

and other

government

units on

budgets.
Whether this diffusion of Participatory

Budgeting (PB) is seen as cause for

celebration or cause for alarm should depend

on both how PB is interpreted and how it is

being implemented in its new environs.

Interpretations of $\mathrm{PB}$, especially as practiced

in Porto Alegre, the Brazilian city that named and publicized it, abound. Yet studies of how PB is practiced, especially outside of Brazil, are only beginning to emerge. Most

importantly, systematic comparisons of the variety of ways in which $\mathrm{PB}$ is designed and implemented in practice remain exceptional. With the aim of contributing to this emerging area of scholarship, this chapter attempts a preliminary analysis of the more recent efforts at introducing participatory

mechanisms into local government budget processes. After a brief section defining PB and outlining its history, I present the major normative perspectives on $\mathrm{PB}$ as well as a number of sometimes corresponding analytical perspectives. Combining arguments made in earlier work, the broad hypothesis I advance is that the design and, partially in turn, the results of PB depend on both the designing actors' intentions and the preexisting conditions in the particular locale. This translates into a number of specific suggestions. The most important of these are that introducing PB is never a neutral political act but rather always a form of "competitive institution building"

(Goldfrank and Schneider, forthcoming), and that the results of PB will vary tremendously. The next section examines these hypotheses through a broad comparison of national experiences in Brazil, Bolivia, Guatemala, Nicaragua, and Peru. This is followed by analysis of case studies in fourteen nonBrazilian municipalities 
Robinson, $M$. (2006) 'Budget Analysis and Policy Advocacy: The Role of Nongovernmental Public Action."

IDS Working Paper 279. Brighton, UK Institute of Development Studies.
Multi-

country Client

case Power

studies

(2)

1) Improved

various

various

Case-

study/

Qualitativ

Improved

Delivery

and

redistribut

ion
Budget

monitoring

initiatives can

contribute to

improved

budget

transparency

and awareness,

as well as

enhanced

resources and

efficiency in

expenditure

utilization
Freedom of

information

requests can

contribute to

responsiveness

of public

officials, though

not always, and

highly

dependent on

status of person

submitting

request and

civil society
This paper examines the impact and

significance of independent budget analysis and advocacy initiatives that are designed to improve budget transparency and the poverty focus of government expenditure priorities. It draws on case study research of six budget groups in Brazil, Croatia, India, Mexico, South Africa, and Uganda, which include non-governmental organisations, research institutions and social movements. The

findings demonstrate that civil society budge initiatives contribute to improvements in the transparency of budgetary decisions and the budget process, increased budget awareness and literacy, and deeper engagement in the

budget process on the part of legislators, the media and civil society organisations. While the structure of the budget process makes substantial changes in expenditure priorities difficult to achieve, budget groups directly contribute to positive impacts on budget allocations and improved implementation, thereby increasing the accountability of decision-makers. Tracking of budgetary expenditures and impacts was also found to be effective in ensuring effective utilisation of education and health expenditures.

Increased budget allocations and improved utilisation of public funds that benefit poor and disadvantaged groups can ensure greater equity in budget priorities and further social justice objectives. The activities of budget groups strengthen democracy by fostering accountability, enhancing transparency and deepening participation.

This report records and analyzes the results of a study in which partners of the Justice Initiative in 14 countries filed a total of 1,926 requests for information. In each country, seven different requesters twice submitted up to 70 questions to 18 public institutions.

Requesters included NGOs, journalists, businesspersons, non-affiliated persons, and members of excluded groups, such as illiterate or disabled persons or those from vulnerable minorities. The requests were for the types of information that public bodies hold - or should hold. As far as possible, no requests were made for classified

information and other information that would 


\begin{tabular}{|c|c|c|c|c|c|c|c|c|c|}
\hline & & & & & & & & & $\begin{array}{l}\text { ordinarily be exempted under standard access } \\
\text { to information legislation. Summary of } \\
\text { findings: 1) Access to Information laws } \\
\text { increase responsiveness 2) Mute refusals are } \\
\text { still a significant problem with } 38 \% \text { of } \\
\text { requests made in countries with FOI laws } \\
\text { going unanswered. 3) Regional variations } \\
\text { exist 4) Civil society involvement helps 5) } \\
\text { Discrimination affected response rates. } \\
\text { Requesters participating in the study who } \\
\text { were journalists or representatives of NGOs } \\
\text { and who identified themselves as such when } \\
\text { making their requests tended to receive } \\
\text { responses more often than individuals who } \\
\text { identified themselves as members of an } \\
\text { excluded or vulnerable group 6) Results } \\
\text { Inconsistent, Even in the Most Responsive } \\
\text { Countries suggesting a lack of training of } \\
\text { government officials }\end{array}$ \\
\hline $\begin{array}{l}\text { Jenkins, } R .(2007) \\
\text { 'India's Unlikely } \\
\text { Democracy: Civil } \\
\text { Society versus } \\
\text { Corruption.' } \\
\text { Journal of } \\
\text { Democracy 18(2): } \\
\text { 55-69. }\end{array}$ & India & $\begin{array}{l}\text { Client } \\
\text { Power }\end{array}$ & $\begin{array}{l}\text { 1) Improved } \\
\text { information }\end{array}$ & $\begin{array}{l}\text { Freedom of } \\
\text { Information } \\
\text { laws }\end{array}$ & $\begin{array}{l}\text { Civil societies } \\
\text { (like MKSS) } \\
\text { spearheaded } \\
\text { movement } \\
\text { leading to RTI } \\
\text { Act. }\end{array}$ & $\begin{array}{l}\text { Qualitativ } \\
\text { e }\end{array}$ & $\begin{array}{l}\text { Reduced } \\
\text { corruption }\end{array}$ & $\begin{array}{l}\text { The Right to } \\
\text { information } \\
\text { campaign in } \\
\text { India led to new } \\
\text { legislation and } \\
\text { widely } \\
\text { mobilised } \\
\text { constituencies } \\
\text { to use } \\
\text { information for } \\
\text { developmental } \\
\text { purposes. }\end{array}$ & $\begin{array}{l}\text { This paper provides a historical overview of } \\
\text { the two anti-corruption waves in India during } \\
\text { the } 90 \text { s and } 2000 \text { s. It describes the concerted } \\
\text { political and civil society efforts that led up } \\
\text { to the } 2003 \text { Right to Information Act in an } \\
\text { effort to reduce corruption in government } \\
\text { programs targeted to the poor. }\end{array}$ \\
\hline $\begin{array}{l}\text { Kwaja, Asim Ijaz. } \\
(2001), \text { 'Can good } \\
\text { projects succeed in } \\
\text { Bad Communities? } \\
\text { Collective Action in } \\
\text { the Himalayas', } \\
\text { Harvard } \\
\text { University, } \\
\text { Department of } \\
\text { Economics, } \\
\text { Cambridge, Mass }\end{array}$ & India & $\begin{array}{l}\text { Compact, } \\
\text { Client } \\
\text { Power }\end{array}$ & $\begin{array}{l}\text { Community } \\
\text { Participation } \\
\text { (CDD) }\end{array}$ & $\begin{array}{l}\text { Citizens are } \\
\text { involved in } \\
\text { prioritizing } \\
\text { and planning } \\
\text { the delivery } \\
\text { of public } \\
\text { goods }\end{array}$ & & $\begin{array}{l}\text { Quantitati } \\
\text { ve (fixed } \\
\text { effects, } \\
\text { with IV) }\end{array}$ & $\begin{array}{l}\text { Public } \\
\text { good } \\
\text { provision }\end{array}$ & $\begin{array}{l}\text { Community- } \\
\text { managed } \\
\text { projects are } \\
\text { better } \\
\text { maintained than } \\
\text { projects } \\
\text { managed by the } \\
\text { local } \\
\text { government. } \\
\text { Also, } \\
\text { community } \\
\text { participation in } \\
\text { tehchnical } \\
\text { decisions } \\
\text { reduced the } \\
\text { quality of } \\
\text { maintenance, } \\
\text { whereas } \\
\text { community }\end{array}$ & $\begin{array}{l}\text { The lack of "social capital" is increasingly } \\
\text { forwarded as an explanation for why } \\
\text { communities perform poorly. Yet, to what } \\
\text { extent can these community-specific } \\
\text { constraints be compensated? I address this } \\
\text { question by examining determinants of } \\
\text { collective success in a costly problem in } \\
\text { developing economies - the upkeep of local } \\
\text { public goods. A difficulty is obtaining } \\
\text { reliable outcome measures for comparable } \\
\text { collective tasks across well-defined } \\
\text { communities. In order to resolve this I } \\
\text { conduct detailed surveys of community- } \\
\text { maintained infrastructure projects in } \\
\text { Northern Pakistan. The findings show that } \\
\text { while community-specific constraints do } \\
\text { matter, they can be compensated by better } \\
\text { project design. Inequality, social } \\
\text { fragmentation, and lack of leadership in the }\end{array}$ \\
\hline
\end{tabular}




\begin{tabular}{|c|c|c|c|c|c|c|c|}
\hline & & & & & & $\begin{array}{l}\text { participation in } \\
\text { non-technical } \\
\text { decisions } \\
\text { significantly } \\
\text { improved } \\
\text { maintenance. }\end{array}$ & $\begin{array}{l}\text { community do have adverse consequences } \\
\text { but these can be overcome by changes in } \\
\text { project complexity, community participation } \\
\text { and return distribution. Using community } \\
\text { fixed effects and instrumental variables } \\
\text { offers a significant improvement in empirical } \\
\text { identification over previous studies. } \\
\text { Moreover, the evidence suggests that better } \\
\text { design matters even more for communities } \\
\text { with poorer attributes. Projects can be } \\
\text { designed to succeed even in "bad" } \\
\text { communities. }\end{array}$ \\
\hline $\begin{array}{l}\text { Mansuri, G. and V. } \\
\text { Rao, } \\
\text {-Community- } \\
\text { Based and-Driven } \\
\text { Development: A } \\
\text { Critical Review, } \\
\text { The World Bank } \\
\text { Research Observer, } \\
\text { 19:1(2004), 1-39. }\end{array}$ & $\begin{array}{l}\text { Various / } \\
\text { lit review }\end{array}$ & $\begin{array}{l}\text { Compact, } \\
\text { Client } \\
\text { Power, } \\
\text { Politics }\end{array}$ & $\begin{array}{l}\text { Community } \\
\text { Participation } \\
\text { (CDD) }\end{array}$ & $\begin{array}{l}\text { Citizens are } \\
\text { involved in } \\
\text { prioritizing } \\
\text { and planning } \\
\text { the delivery } \\
\text { of public } \\
\text { goods }\end{array}$ & $\begin{array}{l}\text { Public } \\
\text { good } \\
\text { provision }\end{array}$ & $\begin{array}{l}\text { The review } \\
\text { reveals lack of } \\
\text { rigorous } \\
\text { evaluations of } \\
\text { the CDD } \\
\text { approach and } \\
\text { the few rigorous } \\
\text { evaluations } \\
\text { (with the except } \\
\text { of the above } \\
\text { study by Asim } \\
\text { Kwaja), reveal } \\
\text { that CDD is } \\
\text { ineffective in } \\
\text { most cases and } \\
\text { the success } \\
\text { depends largely } \\
\text { on the ability of } \\
\text { implementers to } \\
\text { 'contextualize'. } \\
\text { Therefore, the } \\
\text { author } \\
\text { condones } \\
\text { wholesale } \\
\text { application of } \\
\text { best practices. }\end{array}$ & $\begin{array}{l}\text { Community-based and driven development } \\
\text { projects have become an important form of } \\
\text { development assistance, with the World } \\
\text { Bank's portfolio alone approximating } \$ 7 \\
\text { billion. A review of their conceptual } \\
\text { foundations and evidence on their } \\
\text { effectiveness shows that projects rely on } \\
\text { community participation have not been } \\
\text { particularly effective at targeting the poor. } \\
\text { There is some evidence that such projects } \\
\text { create effective community infrastructure but } \\
\text { not a single study establishes causal } \\
\text { relationship between any outcome and } \\
\text { participatory elements of a community-based } \\
\text { development project. Most such projects are } \\
\text { dominated by elites, and both targeting and } \\
\text { project quality tend to be markedly worse in } \\
\text { more unequal communities. A distinction } \\
\text { between potentially 'benevolent' forms of } \\
\text { elite domination and more pernicious types } \\
\text { of capture is likely to be important for } \\
\text { understanding project dynamics and } \\
\text { outcomes. Several qualitative studies indicate } \\
\text { that the sustainability of community-based } \\
\text { initiatives depends crucially on an enabling } \\
\text { institutional environment, which requires } \\
\text { government commitment, and on } \\
\text { accountability of leaders to their community } \\
\text { to avoid 'supply-driven demand driven } \\
\text { development. External agents strongly } \\
\text { influence project success, but facilitators are } \\
\text { often poorly trained, particularly in rapidly } \\
\text { scaled-up programs. The naïve application of } \\
\text { complex contextual concepts like } \\
\text { participation, social capital, and } \\
\text { empowerment is endemic among project } \\
\text { implementers and contributes to poor design } \\
\text { and implementation. The evidence suggests }\end{array}$ \\
\hline
\end{tabular}




\begin{tabular}{|c|c|c|c|c|c|c|c|c|c|}
\hline & & & & & & & & & $\begin{array}{l}\text { that community-based and -driven } \\
\text { development projects are best undertaken in } \\
\text { a context-specific manner, with a long time } \\
\text { horizon and with careful and well-designed } \\
\text { monitoring and evaluation systems. }\end{array}$ \\
\hline $\begin{array}{l}\text { Wantcheckon L. } \\
\text { (2002), } \\
\text { "Clientelism and } \\
\text { Voting Behavior: A } \\
\text { field Experiment in } \\
\text { Benin", New York } \\
\text { University }\end{array}$ & Benin & Politics & $\mathrm{n} / \mathrm{a}$ & $\mathrm{n} / \mathrm{a}$ & $\mathrm{n} / \mathrm{a}$ & RCT & & $\begin{array}{l}\text { The results } \\
\text { indicate that } \\
\text { women voters } \\
\text { have stronger } \\
\text { preference for } \\
\text { public goods } \\
\text { than men, and } \\
\text { that younger } \\
\text { and older voters } \\
\text { have similar } \\
\text { policy } \\
\text { preferences }\end{array}$ & $\begin{array}{l}\text { I conducted a field experiment in Benin to } \\
\text { investigate the impact of clientelism on } \\
\text { voting behavior. In collaboration with four } \\
\text { political parties involved in the } 2001 \\
\text { presidential elections, clientelist and } \\
\text { programmatic platforms were designed and } \\
\text { run in twenty randomly selected villages of } \\
\text { an average of } 756 \text { registered voters. Even } \\
\text { after controlling for ethnic affiliation, I find } \\
\text { that clientelist platforms have significant } \\
\text { effect on voting behavior. The effect was } \\
\text { strongest for incumbent and for "local" } \\
\text { candidates. The evidence indicates that } \\
\text { "national" candidates have comparative } \\
\text { advantage over "local" candidates on } \\
\text { programme. In addition, the less clientelist is } \\
\text { the platform of the "national" opposition } \\
\text { candidate, the better is his electoral prospect } \\
\text { among female voters. }\end{array}$ \\
\hline $\begin{array}{l}\text { Khemani, S and } \\
\text { Kheefer, } P \text { "The } \\
\text { Role of Mass } \\
\text { Media in } \\
\text { Developing } \\
\text { Democracies:Impa } \\
\text { ct of Radio on the } \\
\text { Distribution of } \\
\text { Anti-malaria Bed } \\
\text { Nets in Benin", } \\
\text { World Bank Draft } \\
\text { (May 2011) }\end{array}$ & Benin & $\begin{array}{l}\text { Compact, } \\
\text { Client } \\
\text { Power. } \\
\text { Politics }\end{array}$ & $\begin{array}{l}\text { 1) Improved } \\
\text { information }\end{array}$ & $\begin{array}{l}\text { Radios } \\
\text { disseminate } \\
\text { information } \\
\text { on the } \\
\text { availabitliy of } \\
\text { free bed nets } \\
\text { and of their } \\
\text { importance in } \\
\text { reducing the } \\
\text { contraction } \\
\text { and spread of } \\
\text { Malaria }\end{array}$ & $\begin{array}{l}\text { It is usually } \\
\text { hypothesized } \\
\text { that increased } \\
\text { information } \\
\text { could improve } \\
\text { collective } \\
\text { action capacity } \\
\text { of clients to } \\
\text { increase } \\
\text { government } \\
\text { accountability. }\end{array}$ & $\begin{array}{l}\text { Natural } \\
\text { Experime } \\
\text { nt - } \\
\text { Exploiting } \\
\text { quasi- } \\
\text { random } \\
\text { radio } \\
\text { coverage } \\
\text { within } \\
\text { commune }\end{array}$ & $\begin{array}{l}\text { Public } \\
\text { good } \\
\text { provision }\end{array}$ & $\begin{array}{l}\text { Increased } \\
\text { information } \\
\text { resulted in an } \\
\text { greater usage of } \\
\text { bed nets. } \\
\text { However, this } \\
\text { was the result } \\
\text { of individual } \\
\text { households } \\
\text { investing more } \\
\text { of their own } \\
\text { resources in } \\
\text { acquiring bed } \\
\text { nets as opposed } \\
\text { to higher levels } \\
\text { of provision of } \\
\text { free bed nets by } \\
\text { government }\end{array}$ & $\begin{array}{l}\text { Government provision of free or subsidized } \\
\text { bed nets to combat malaria in Africa is an } \\
\text { important policy context to examine } \\
\text { unanswered questions regarding the } \\
\text { influence of mass media on household } \\
\text { political behavior and health practices in } \\
\text { poor democracies. Does radio access enable } \\
\text { citizens to receive greater private benefits } \\
\text { from government programs (in this case, free } \\
\text { bed nets), as it does in richer countries? Does } \\
\text { it persuade households to invest more of thei } \\
\text { own resources to acquire bed nets? Using a } \\
\text { "natural experiment" in radio markets in } \\
\text { northern Benin, which provide for exogenous } \\
\text { variation in village access to community } \\
\text { radio, we find that households in villages } \\
\text { with greater radio access are more likely to } \\
\text { acquire bed nets using their own resources; } \\
\text { they are not more likely to receive them for } \\
\text { free from government sources. This } \\
\text { evidence, consistent with other evidence on } \\
\text { education in Benin, suggests that in poor } \\
\text { democracies mass media are more likely to } \\
\text { be persuasive in changing the private } \\
\text { behavior of poor citizens- in this case, to }\end{array}$ \\
\hline
\end{tabular}




\begin{tabular}{|c|c|c|c|c|c|c|c|c|c|}
\hline & & & & & & & & & $\begin{array}{l}\text { invest more of their own resources on a good } \\
\text { with large positive externalities (bed nets)- } \\
\text { rather than enabling citizens to extract } \\
\text { greater benefits from government. }\end{array}$ \\
\hline $\begin{array}{l}\text { Khemani, S and } \\
\text { Kheefer, P "When } \\
\text { Do Legislators } \\
\text { Pass on Pork? The } \\
\text { Role of Political } \\
\text { Parties in } \\
\text { Determining } \\
\text { Legislator Effort", } \\
\text { American Political } \\
\text { Science Review, } \\
\text { Vol. 103, No. } 1\end{array}$ & India & Compact & $\begin{array}{l}\text { 1) Compact } \\
\text { between } \\
\text { party leaders } \\
\text { and } \\
\text { legislators is } \\
\text { linked to } \\
\text { level of } \\
\text { party } \\
\text { attachement } \\
\text { in the } \\
\text { legislator's } \\
\text { constituency }\end{array}$ & $\begin{array}{l}\text { Through } \\
\text { seleciton of } \\
\text { legislators } \\
\text { with the } \\
\text { correct } \\
\text { preferences }\end{array}$ & $\mathrm{n} / \mathrm{a}$ & $\begin{array}{l}\text { Quantitati } \\
\text { ve }\end{array}$ & $\begin{array}{l}\text { Public } \\
\text { good } \\
\text { provision }\end{array}$ & $\begin{array}{l}\text { In areas where } \\
\text { voters display } \\
\text { strong } \\
\text { attachement to } \\
\text { party, } \\
\text { legislators exert } \\
\text { lower effort in } \\
\text { using their } \\
\text { discretionary } \\
\text { funds to } \\
\text { implement } \\
\text { projects. The } \\
\text { authors } \\
\text { interpret this } \\
\text { finding as an } \\
\text { indication that } \\
\text { party leaders } \\
\text { can afford to } \\
\text { select } \\
\text { legislators } \\
\text { whose } \\
\text { preferences are } \\
\text { more aligned to } \\
\text { party } \\
\text { preferences } \\
\text { rather than } \\
\text { concerned with } \\
\text { their } \\
\text { constituents in } \\
\text { those areas } \\
\text { where there is } \\
\text { strong party } \\
\text { attachment. }\end{array}$ & $\begin{array}{l}\text { A central challenge in political economy is to } \\
\text { identify the conditions under which } \\
\text { legislators } \\
\text { to "bring home the pork" to constituents. We } \\
\text { conduct the first systematic analysis of one } \\
\text { determinant } \\
\text { of constituency service, voter attachment to } \\
\text { political parties, holding constant electoral } \\
\text { and political institutions. Our analysis takes } \\
\text { advantage of data from a unique type of } \\
\text { public spending } \\
\text { program that is proliferating across } \\
\text { developing countries, the constituency } \\
\text { development fund } \\
\text { which offers more precise measures of } \\
\text { legislator effort than are common in the } \\
\text { literature. Examining } \\
\text { the CDF in India, we find that legislator } \\
\text { effort is significantly lower in constituencies } \\
\text { that are party } \\
\text { strongholds. This result, which is robust to } \\
\text { controls for alternate explanations, implies } \\
\text { that legislators } \\
\text { pass on pork when voters are more attached } \\
\text { to political parties. It has implications not } \\
\text { only for understanding } \\
\text { political incentives and the dynamics of party } \\
\text { formation, but also for evaluating the impact } \\
\text { of a } \\
\text { CDFs. }\end{array}$ \\
\hline
\end{tabular}


Khemani, $S$ and Kheefer, $P$ "Mass Media and Public Services: The Effects of Radio Education in Benin", World Bank Policy Research Working Paper, WPS5559 Access on Public
Radios

disseminate information Compact

Benin Client

Power,

Politics information infrastructure and services educational
It is usually hypothesized that increased information could improve collective action capacity of clients to increase government accountability.

\section{Schaffer, $F$}

"Disciplinary

Reactions:

Alienation and the

Reform of Vote

Buying in the

Philippines", MIT

2002

\section{Philippin Politics}

1)

Regulating

the electoral system
Implementing

electoral

reforms to

fight vote-

buying
The main take-
Increased information resulted in an increase in access and usage of education facilities but the change came from changes in household

behavior (greater demand for education) rather than better

government accountability

Does radio access improve public service provision? And if so, does it do so by increasing government accountability to citizens, or by persuading households to take advantage of publicly-provided services? Prior research has argued that citizens with greater access to mass media receive greater benefits from targeted government welfare programs, but has not addressed these questions for public services such as in education and health. Using unique data from Benin, this paper finds that literacy rates among school children are higher in villages exposed to signals from a larger number of community radio stations. The effect is identified based on a "natural experiment" in the northern communes of Benin where within-commune variation in village access to radio stations is exogenous to observed and unobserved village characteristics. In contrast to prior research, the authors find that this media effect does not operate through government accountability: government inputs into village schools and household knowledge of government education policies are no different in villages with greater access to community radio. Instead, households with greater access are more likely to make financial investments in the education of their children.

Theoretical

conclusions

described in

abstract -->.

away is that

electoral

reforms that

address vote-

buying can

sometimes have

unintended

second-hang

complications

and costs that

do not justify

these reforms.

Through the

case study of

the Philippines important issues and questions unaddressed. With regard to the Philippine case alone, it has little to say about how rural voters view vote buying and efforts to reform it, or the distinctive contribution of upper class reformers to the misrepresentation of the urban poor. It has not discussed the views of vote-buying politicians, those who bankroll them, or members of the higher classes who distance themselves from reformist groups. Nor has this analysis delved into the question of whether vote buying is really a serious defect of the Philippine and Thai electoral sellers reflect instead middle class fantasies and anxieties blown out of proportion. Callahan $(2002,24)$ goes so far as to argue that in Thailand "vote-buying is not as big a problem as is our obsession with it." It could systems, or whether efforts to discipline vote 


\begin{tabular}{|c|c|c|c|c|c|c|c|c|c|}
\hline & & & & & & & & $\begin{array}{l}\text { Schaffer shows } \\
\text { the important of } \\
\text { context in } \\
\text { assessing the } \\
\text { viability of such } \\
\text { reforms. }\end{array}$ & $\begin{array}{l}\text { thus be asked why reformers in both } \\
\text { countries have not tried to change more } \\
\text { earnestly the deeper political and economic } \\
\text { structures which have given rise to a host of } \\
\text { extra-legal political practices, of which vote } \\
\text { buying is but one. Or it might be asked why } \\
\text { reformers have not focused more intensively } \\
\text { on other, more clearly nefarious, practices } \\
\text { such as the use of violence as an election } \\
\text { strategy. In the May } 2001 \text { Philippine } \\
\text { elections there were } 100 \text { election related } \\
\text { deaths, with another } 141 \text { people wounded. } \\
\text { When } 76 \text { people were killed and } 26 \text { injured } \\
\text { in the } 2002 \text { barangay elections, the } \\
\text { COMELEC chairman expressed satisfaction } \\
\text { that it was "generally peaceful," while the } \\
\text { PPCRV charmain chairman described the } \\
\text { violent incidents,- which included } 42 \\
\text { shootings, } 9 \text { liquidations, } 7 \text { gunfights, } 6 \\
\text { ambushes, } 3 \text { cases of harassment, } 3 \text { strafings, } \\
3 \text { abductions, and } 2 \text { bombings - as "isolated". }\end{array}$ \\
\hline $\begin{array}{l}\text { Vincente, P (2010) } \\
\text { "Is Vote-buying } \\
\text { Effective? Evidence } \\
\text { from a Field } \\
\text { Experiment in West } \\
\text { Africa", Oxford } \\
\text { University and } \\
\text { BREAD }\end{array}$ & $\begin{array}{l}\text { Sao } \\
\text { Tome } \\
\text { and } \\
\text { Principe }\end{array}$ & Politics & $\begin{array}{l}\text { 1) Improved } \\
\text { information }\end{array}$ & $\begin{array}{l}\text { Improving } \\
\text { information } \\
\text { on the legal } \\
\text { structure of } \\
\text { the electoral } \\
\text { system, } \\
\text { namely, on } \\
\text { the illegal } \\
\text { nature of } \\
\text { vote-buying }\end{array}$ & $\begin{array}{l}\text { Voters attended } \\
\text { voter education } \\
\text { campaign } \\
\text { organized by } \\
\text { the National } \\
\text { Electoral } \\
\text { Commission }\end{array}$ & RCT & $\begin{array}{l}\text { Electoral } \\
\text { outcomes }\end{array}$ & $\begin{array}{l}\text { Improved } \\
\text { information on } \\
\text { illegality on } \\
\text { vote-buying } \\
\text { reduced the } \\
\text { influence of } \\
\text { money on } \\
\text { outcomes } \\
\text { (although we } \\
\text { are not sure } \\
\text { whether the } \\
\text { information } \\
\text { itself or rather } \\
\text { the perception } \\
\text { of greater } \\
\text { monitoring by } \\
\text { the electoral } \\
\text { commission is } \\
\text { driving the } \\
\text { result) and } \\
\text { favored the } \\
\text { incumbent }\end{array}$ & $\begin{array}{l}\text { Vote-buying, i.e., cash-for-votes, is a } \\
\text { frequent practice during election time in } \\
\text { many parts of the world, namely in West } \\
\text { Africa. However, in the presence of secret } \\
\text { ballots, it is not clear whether vote-buying } \\
\text { drives voting behavior. In order to infer } \\
\text { effects of vote-buying on electoral behavior, } \\
\text { we designed and conducted a randomized } \\
\text { field experiment during an election in newly } \\
\text { oil-rich Sao Tome and Principe. We follow a } \\
\text { voter education campaign against votebuying } \\
\text { sponsored by the Electoral Commission, } \\
\text { using panel-survey measurements as well as } \\
\text { actual electoral data per ballot station. Our } \\
\text { results show that the campaign reduced the } \\
\text { influence of money offered on voting, } \\
\text { decreased electoral participation, and favored } \\
\text { the incumbent. This evidence suggests that } \\
\text { vote-buying increases voter turnout and that } \\
\text { the challenger drives relatively more votes } \\
\text { through vote-buying - i.e., vote-buying } \\
\text { counteracts the incumbency advantage. }\end{array}$ \\
\hline
\end{tabular}


Pande, R (2011)

"Can Informed

Voters Enforce

Better

Governance?

Experiments in

Low Income

Democracies",

Annual Review of

Economics
India

Politics

represented

groups

2) Educating

voters about

importance of

politics and

the potential

costs of

electoral

malpractice

and identity

politics

Banerjee, $A$,

Green, $D \&$ Pande

$R$ "Can Voters be

Primed to Choose

Better Legislators?

Experimental

Evidence from

Rural India",

Preliminary and

Incomplete
2 voter

awareness

campaigns to

priming

voters to not

India

Politics
1) Improved

information vote for

corrupt

candidates

and to not

vote for

candidates

based only on

caste

NGOs and civil

societies

organize

awareness

campaigns to

educate and

inform voters

Electoral

outcomes

Better-

performing

politicians are

elected and

there is a

decrease in the

extent of

electoral

malpractice and

the level of

identity politics

(caste)

2 prominent

NGOs

organized

awareness

campaigns to

educate and

inform voters
RCT

Electoral

outcomes
Ethnic

preferences can

be altered by

disseminating

information on

the quality of

politicians,

providing a

means to move

away from

identity politics

and also select

better and less

corrupt

politicians
This article evaluates a body of recent work which uses field and natural experiments to answer this question. A common finding in the literature is that voter behavior is malleable and that information about the political process and politician performance improves electoral accountability. Limited availability of information thus provides one explanation for the persistence of low quality politicians and the existence of identity politics and electoral malpractices in lowincome democracies. Understanding how voters can gain access to credible sources of information and how politicians react to improved information about their performance are promising avenues for future research.

Ethnic politics and political corruption are important concerns in many developing country democracies. We conducted eld experiments in rural India to examine the responsiveness of voter preferences to priming about the relevance of ethnicity and politician quality for service delivery. We used vignette experiments to examine how voter preferences vary with information about politician quality. We nd strong evidence that ethnic preferences are malleable. The vignette experiments show that ethnic preferences respond to politician quality and the field experiment shows that reductions in ethnic voting reduce the vote share of criminal politicians. In contrast, priming voters on the relevance of corruption left electoral outcomes una ected (in the field experiment). We interpret these results in the context of a model where a voter's use of specific evaluative criteria is influenced by available information. 
Ferraz, $C$ and

Finan, $F$

"Reelection

Incentives and

Political

Corruption:Eviden

ce from Brazilian

Audit Reports",

2005 Annual

meeting, July 24-

27, Providence, RI,

Brazil

Politics

This paper uses audit data from Brazil to test political agency models on corruption that predict that 2 nd and 3 rd term

politicians will tend to be more corrupt than 1st term

politician. Their unique dataset confirms the model's predictions.

\section{Agricultural}

Economics

Association (New

Name 2008:

Agricultural and

Applied Economics

Association)
Bobonis, $G$,

Fuertes, $C$,

Schwabe, $R$ (2011)

"The Dynamic

Effects of

Information on

Political

Corruption:Theory

and Evidence from

Puerto Rico",

Working Papers

from University of

Toronto,

Department of

Economics
Re-election incentives can influence the level of corruption in politicians.

While political agency models may predict that politicians who benefit whose reputation goes up will tend to exploit the 'slack' they receive by Providing 1) Improved information Rico

Politics

\section{on corruption} level of politicians
Naturally

random auditing of municipali ties
As part of a recent anti-corruption campaign, the Brazilian government began to audit the municipal expenditure of federally-

transferred funds. Using these audit reports, we construct a unique data set of political corruption to test whether reelection incentives affect the level of corruption in a municipality. Consistent with a political economy agency model, we find that mayors who are in their second and final term are significantly more corrupt than first-term mayors. In particular, second-term mayors on average divert, $\mathrm{R} \$ 188,431.4$ more than firstterm mayors, which is approximately 4 percent of the total amount transferred to municipalities. We also find much more pronounced effects among municipalities where the costs of rent-extraction are lower, and the density of pivotal voters is higher. Our results also illustrate an important tradeoff: second-term mayors, while more corrupt, provide a higher level of public goods. As Brazil and other countries continue their decentralization process, our findings promote the need for a better understanding of how local institutions can help reduce the incentives for corruption.

Does the disclosure of information about corrupt activities induce a sustained reduction in corruption? We use publicly released routine audits of municipal governments in Puerto Rico to answer this question. We first develop a political agency model where voters re-elect incumbents based on their performance while in office. We show that, because voters cannot directly observe incumbents' actions, an incumbent whose reputation improved in the previous term is likely to engage in more rent-seeking activities in a future term. Guided by this model, we use longitudinal data on audit results to examine the long-term consequences of providing information to voters on levels of political corruption. We find that municipal corruption levels in subsequent audits are on average the same in municipalities audited preceding the previous election and those not audited then. In spite of this, mayors in municipalities audited preceding the previous election have higher 
